\title{
THE SUPERFAMILIES PUPILLOIDEA AND ENOIDEA (GASTROPODA, EUPULMONATA) IN BHUTAN
}

\author{
Edmund GitTenberger ${ }^{1 *}$, CHOKI Gyeltshen ${ }^{2}$, PEMA LEDA $^{2}$, SHERUB SHERUB $^{3}$ \\ ${ }^{1}$ Mollusca, National Biodiversity Center Naturalis/Leiden University (retired), The Netherlands \\ (e-mail: egittenberger@yahoo.com); (1) https://orcid.org/0000-0002-8209-7656 \\ ${ }^{2}$ General Management, National Biodiversity Centre, Serbithang, Ministry of Agriculture and Forests, \\ Thimphu, Bhutan, Bhutan (e-mail: chokig@gmail.com; pemled12@gmail.com) \\ ${ }^{3}$ General Management, Ugyen Wangchuck Institute for Conservation and Environmental Research, \\ Bumthang, Bhutan, Bhutan (e-mail: sherubird@gmail.com) \\ *corresponding author
}

\begin{abstract}
The species of two gastropod superfamilies, i.e. Pupilloidea and Enoidea, that have been recorded in Bhutan, are described and illustrated. Five families with ten species in total are dealt with. Three species are described as new to science, viz. Pupisoma (P.) paroense Gittenberger et Leda, n. sp., Pseudonapaeus occibhutanus Gittenberger, Gyeltshen et Sherub, n. sp., and Laevozebrinus parvus Gittenberger, Gyeltshen et Leda, n. sp. Distribution maps are presented for all the species. Some biogeographical considerations are added.
\end{abstract}

KEY WORDS: taxonomy; Pupilloidea; Enoidea; distribution; Bhutan

Publication LSID D0FFDEEA-E9DD-49D3-A7F6-3966DE97765C

Pupisoma paroense LSID 3548B71D-F10F-4F5E-89D1-9CB4F8FA9D75

Pseudonapaeus occibhutanus LSID A0D0A357-6619-4149-9FC5-91D8FDAC4F20

Laevozebrinus parvus LSID 2562A8E7-02CD-47A7-A2D1-B7B44D10879E

\section{INTRODUCTION}

The description of Truncatellina bhutanensis by GITTENBERGER et al. (2013) marks the beginning of the malacological inventory of the Kingdom of Bhutan, which took place with fieldwork from 2012 on. This geographically very diverse country is cut by high mountain chains with corresponding deep valleys. It belongs to the SE. Himalayan border zone. It has a surface of $38,394 \mathrm{~km}^{2}$, with an altitude of ca. $100 \mathrm{~m}$ a.s.l. in the south and over 7,500 $\mathrm{m}$ a.s.l. in the north. For a more detailed account, see GITTENBERGER et al. (2018a). Meanwhile there has been a gradual increase in our knowledge of the gastropods and bivalves of that country. In a preliminary fieldguide
(GITTENBERGER et al. 2017) a first draft of the diverse molluscan fauna was published, inevitably with many uncertainties and far from complete in many respects. With an ongoing, stepwise approach we aim at an improved summary for the Bhutanese molluscs, their taxonomy and distribution. Here we present the first results of our inventory for the species of two superfamilies, viz. Pupilloidea and Enoidea. We are aware of the fact that this article offers an incomplete coverage of the existing malacofauna regarding these taxa since large areas in the country are still unexplored. Waiting for a more complete picture however, could easily result in lengthy silence. 


\section{MATERIAL AND METHODS}

The specimens were collected without a standardised method, so that the number of specimens in a sample cannot be used as a measure of frequency. Colleting was by eye and by sieving soil samples taken during fieldwork in 2013-2019 within the scope of the Bhutan Evertebrata Inventory Project (see GitTENBERGER et al. 2017). Most specimens are kept in the National Biodiversity Centre, Serbithang, Thimphu, Bhutan. Some duplicates, including paratypes of the new species, are deposited in Naturalis Biodiversity Center, Leiden, The Netherlands. In the type series, the number of specimens, i.e. shells, unless stated otherwise, is indicated after the slash after the registration number.

For every species, except Bensonella plicidens, there is a description on the basis of the specimens from Bhutan. Referring to BUDHA et al. $(2015,2017)$, in their annotated checklist for the Nepalese malacofauna, we mention for every species whether it is known from Nepal. For the names and authorships of the taxa above the species level, we rely on BOUCHET et al. (2017).

The snails were dissected while in ethanol $70 \%$. The genital tract was fixed with needles and shortly stained with cochineal. It was transferred to ethanol $97-100 \%$ before the needles were removed. The hardened tract was then transferred stepwise via Euparal essence to Euparal and mounted for permanent use on a microscopic slide. In the descriptions of the genitalia, under the heading 'Genital tract', we use proximal and distal in relation to the body wall.

Photographs were taken with a Canon EOS 7D, using a Canon Macro Photo Lens Mp-E65mm with a Macro Ring Lite MR-14EXII. The scanning electron microscopic images were taken with a Jeol JSM6480LV.

Abbreviations: $\mathrm{AH}$ - aperture height; a.s.l. - above sea level; AW - aperture width; EG - E. GITTENBERGER leg.; EGCGPL - E. GITTENBERGER, CHOKI GYELTSHEN, PEMA LedA leg.; EGCGKT - E. GITTENBERGer, CHOKI GYELTSHEN, KEZANG TOBGAY leg.; EGPL - E. GitTenberger, PEMA LedA leg.; $\mathrm{H}$ - shell height; $\mathrm{n}$ number of specimens; NBCB - National Biodiversity Centre, Serbithang, Ministry of Agriculture and Forests, Thimphu, Bhutan; NHMUK - Natural History Museum, London, U.K.; RMNH.MOL National Biodiversity Center Naturalis, Leiden, The Netherlands; SMF - Senckenberg Forschungsinstitut und Naturmuseum, Frankfurt am Main, Germany; U - umbilical width; UMZC - University Museum of Zoology, Cambridge, U.K.; W - shell width.

\section{SYSTEMATIC PART}

\section{Order Stylommatophora Infraorder Orthurethra}

\section{Superfamily Pupilloidea Turton, 1831 Family Pupillidae Turton, 1831 \\ Genus Pupilla Fleming, 1828}

Type species: Pupa marginata Draparnaud, 1801 [= Pupilla muscorum (L., 1758)], by monotypy. See Opinion 335 (Hemming 1955: 49).

\section{Pupilla turcmenia (O. Boettger, 1889)}

Figs 1-6

Pupa (Pupilla) cupa var. turcmenia O. BoetTGer (1889: 928, 958, pl. 26 fig. 3a-c), Iran, central "Kopetdagh", summit of "Agh-dagh", "9000-10000" [2,740-3,050 $\mathrm{m}$ a.s.1.]).

Pupilla cupa turcmenia - PILSBRY (1921: 188, pl. 23 figs 6-9).

Pupilla turcmenica - MENG (2008: 224, fig. 5.8), NeKOLA et al. (2014: 204, 212, figs 1, 4E-H), GITTENBERGER et al. (2017: 50, fig. 35).
Pupilla (Pupilla) turcmenica - SCHILEYKO (1984: 190, fig. 108), POKRYSZKO et al. (2009: 447, table 1, figs 56, 61-64).

Material. District Paro: $6.5 \mathrm{~km} \mathrm{~S}$ of Chhuzom, altitude $2,043 \mathrm{~m}$ a.s.l., dry W-facing slope, $27^{\circ} 15.40^{\prime} \mathrm{N}$, 89³1.70'E, EGCGPL 20.10.2018 (NBCB1168; RMNH.MOL.346811); $14 \mathrm{~km}$ SE of Paro, N-side river, near monastery Tachugang Lhakhang, altitude 2,150 m a.s.l., among rocks, near small rockface, $27^{\circ} 20^{\prime} \mathrm{N}, 8^{\circ} 30^{\prime} \mathrm{E}$, EGPL 06.04.2013 (NBCB1118; RMNH.MOL.346812); 9 km SSW of Chhuzom, altitude $2,450 \mathrm{~m}$ a.s.l., rocky S-slope, $27^{\circ} 14^{\prime} \mathrm{N}, 89^{\circ} 30^{\prime} \mathrm{E}$, EGPL 07.04.2013 (NBCB1119); $1.7 \mathrm{~km} \mathrm{SSW} \mathrm{of}$ Chhuzom, W-side of the river, small gully with high rockface at $\mathrm{N}$-side, altitude $2,150 \mathrm{~m}$ a.s.l., $27^{\circ} 18^{\prime} \mathrm{N}$, 89³3'E, EGPL 07.04.2013 (NBCB1120; RMNH. MOL.346813); S of Paro (= Rinpung) Dzong, E-side river, altitude $2,250 \mathrm{~m}$ a.s.l., $27^{\circ} 25^{\prime} \mathrm{N}, 89^{\circ} 25^{\prime} \mathrm{E}$, EGPL 11.04.2013 (NBCB1121; RMNH.MOL.346814). District Thimphu: $17 \mathrm{~km}$ SE Paro, near bridge, N-side river, altitude 2,100 $\mathrm{m}$ a.s.l., $27^{\circ} 19^{\prime} \mathrm{N}, 89^{\circ} 34^{\prime} \mathrm{E}$, EGPL 06.04.2013 (NBCB1122). 
Description. The brown to yellowish brown, rather fragile shell has $5^{1 / 2}-6^{1} / 2$ moderately convex whorls, separated by an incised suture; it is cylindrical with a convex-conical apical part, encompassing a third to nearly half of the total shell height. The protoconch is very finely granular. The teleoconch has a characteristic sculpture of prosocline riblets $(14-16 / \mathrm{mm})$ that are slightly heightened by periostracal ridges. In between the riblets there is an irregular sculpture of some radial lines on a silky background and a vague pattern of periostracal wrinkles. The umbilicus is less than $3 \% \mathrm{~W}$ broad and not always visible as a hole in strict basal view. The aperture ascends to about half the height of the penultimate whorl; it is little higher than broad $(\mathrm{AH} / \mathrm{AW}=1.05-1.17)$ and its height is $28-35 \% \mathrm{H}$. Except for the parietal side, there is a broadly reflected apertural lip. About halfway at the parietal side there is a moderately prominent parietal tubercle and near the palatal-basal transition there is an equally prominent second callosity, elongated as a quickly fading lamella inside the aperture. At the outside, shortly behind the apertural lip, there is a distinct rib that may have a lighter colour than the rest of the shell; behind it, the shell is somewhat flattened, sometimes with a faint indentation corresponding with the lamella inside the aperture.

Measurements $(\mathrm{n}=40)$. H 2.88-3.55 mm, W 1.66$1.88 \mathrm{~mm}$.

Distribution. This is a widespread Asian species, known from NE Iran (Kopet Dagh), northern Afghanistan and the province of Balochistan in Pakistan in the west, and as far eastwards as W China (Tien Shan and Tibet) (POKRYSZKO et al. (2009: 448). In Bhutan it was recorded only in the western districts of Paro and Thimphu, at altitudes of 2,040-2,450 $\mathrm{m}$ a.s.1.

Notes. Recent authors incorrectly use the epithet turcmenica.
P. turcmenia resembles its sister species P. sterrii (Voith, 1840) (NEKOLA et al. 2014: 204, fig. 1) in shell shape and sculpture. SCHILEYKO (1984: 190, fig. 108), MENG (2008: 224), SYSOEV \& SCHILEYKO (2009: 46, fig. 19D), and POKRYSZKO et al. (2009: table 1) illus-

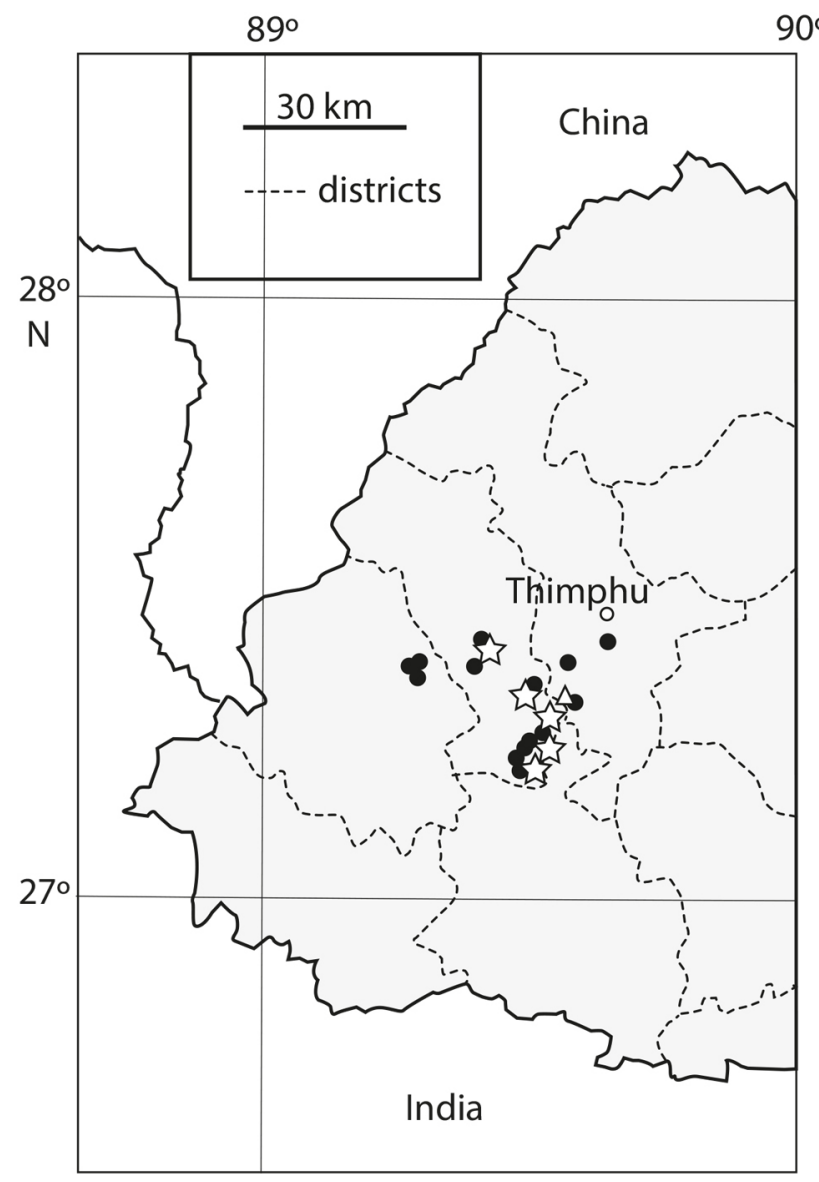

Fig. 6. Records of Pupilla turcmenia (O. Boettger, 1889) and Gastrocopta huttoniana (Benson, 1849) together (stars), or only P. turcmenia (triangle), or only G. huttoniana (dots)

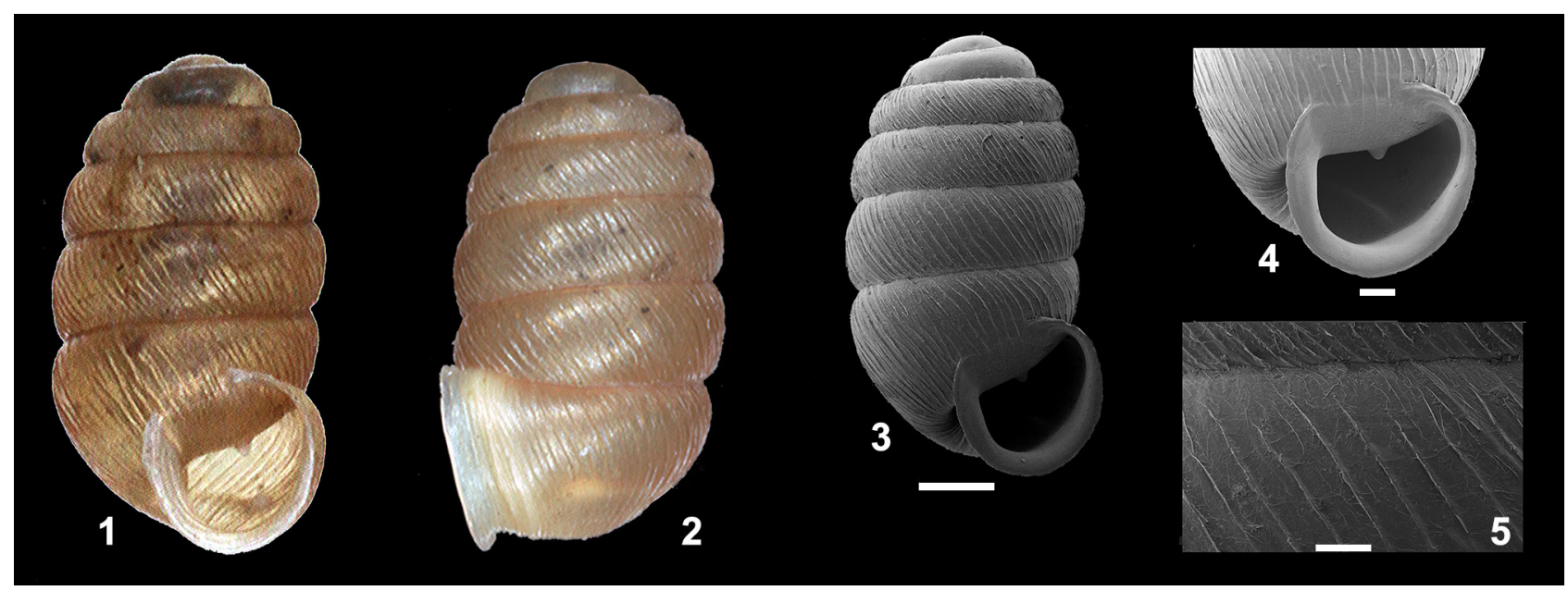

Figs 1-5. Pupilla turcmenia (O. Boettger, 1889) (NBCB1120), district Paro, $1.7 \mathrm{~km}$ SSW of Chhuzom, altitude 2,150 m a.s.l.: 1-2 - shell, H 3.20 mm, 3 - H 2.94 mm, 4 - aperture, 5 - teleoconch sculpture. Scale bars $0.5 \mathrm{~mm}(3), 200 \mu \mathrm{m}$ (4), $100 \mu \mathrm{m}(5)$ 
trate or describe shells of $P$. turcmenia with a parietal denticle at most in the aperture. According to NEKOLA et al. (2014: 211) however, the number of apertural 'lamellae' varies from 0 to 3 . In all our specimens from Bhutan there is not only a tubercular parietalis but also a slightly elongated, lamella-like palatalis. The shells are clearly P. turcmenia, in particular also by the characteristic sculpture of radial periostracal riblets. $P$. turcmenia is not known from Nepal. In that country the genus is represented with certainty only by $P$. eurina (Benson, 1864) and P. triplicata (Studer, 1820) (BUDHA 2015: 10; 2017: 25).

\section{Family Gastrocoptidae Pilsbry, 1918}

\section{Genus Gastrocopta Wollaston, 1878}

Type species: Pupa acarus Benson, 1856, by subsequent designation (PILSBRY 1916: 7). See Direction 72 (HeMming 1957: 167).

\section{Gastrocopta huttoniana (Benson, 1849)}

Figs 6-8

Pupa huttoniana BENSON (1849: 126), India, Himachal Pradesh, "Simla" [Shimla].

Gastrocopta huttoniana - POKRYSZKO et al. (2009: 433, figs 26-28), RAHEEM et al. (2010: unnumbered fig.), RAMAKRISHNA et al. (2010: 122), RAHEEM et al. (2014: 64, 184, figs 37A [lectotype], 37B), BUDHA et al. (2015: 11; 2017: 26), GITTENBERGER et al. (2017: 54, fig. 39), BÖSSNECK \& MENG (2018: 135, 136, figs 1, 2).

Material. District Haa: $15 \mathrm{~km}$ WSW of Paro, altitude $3,100 \mathrm{~m}$ a.s.l., $27^{\circ} 22^{\prime} \mathrm{N}, \quad 89^{\circ} 17^{\prime} \mathrm{E}$, EGPL

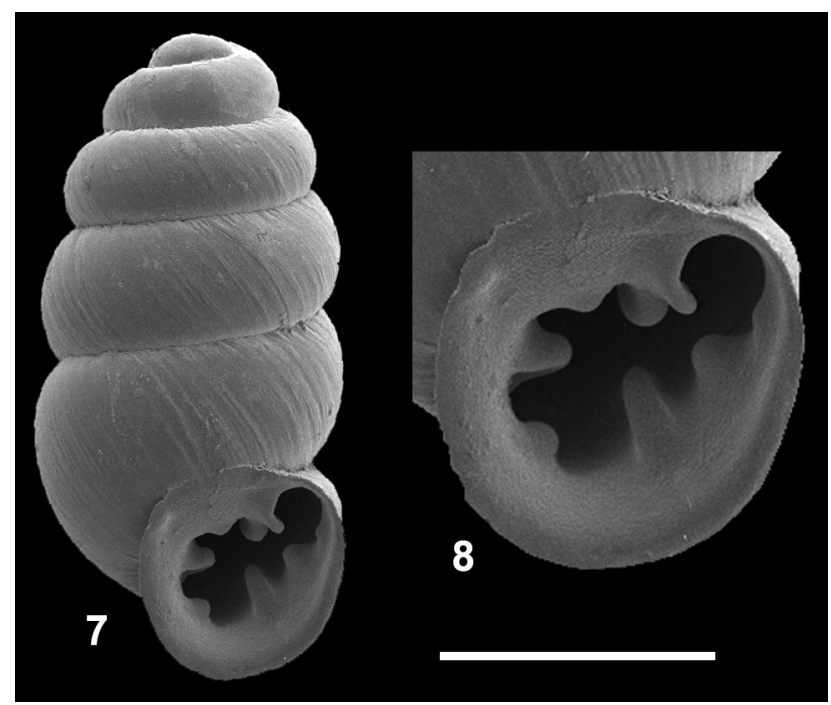

Figs 7-8. Gastrocopta huttoniana (Benson, 1849) (NBCB1159), district Thimphu, road to quarry near Bjimina, $13 \mathrm{~km} \mathrm{SW}$ of Thimphu, altitude 2,300 m a.s.l.: 7 - shell, H $2.08 \mathrm{~mm}, 8$ - aperture, with scale bar $0.5 \mathrm{~mm}$
30.03.2016 (NBCB1192); 4 km NW of Haa, 2,985 $\mathrm{m}$ a.s.l., $\quad 27^{\circ} 23^{\prime} \mathrm{N}, \quad 89^{\circ} 16^{\prime} \mathrm{E}, \quad$ EGPL 30.03 .2016 (NBCB1193). District Paro: road Paro-Haa, altitude 2,250 m a.s.l., $27^{\circ} 23^{\prime} \mathrm{N}, 89^{\circ} 26^{\prime} \mathrm{E}$, EGPL 11.04.2013 (NBCB1191); $14 \mathrm{~km} \mathrm{SE}$ of Paro, $\mathrm{N}$-side river, near monastery Tachugang Lhakhang, altitude 2,150 $\mathrm{m}$ a.s.l., among rocks near small rockface, $27^{\circ} 20^{\prime} \mathrm{N}$, $89^{\circ} 30^{\prime} \mathrm{E}$, EGPL 06.04.2013 (NBCB1152; RMNH. MOL.346815); S-slope E of limestone quarry NW of Dobji Dzong, altitude 2,300 m a.s.l., $27^{\circ} 17^{\prime} \mathrm{N}$, 89³1'E, EGPL 07.04.2013 (NBCB1153); $6.5 \mathrm{~km} \mathrm{~S}$ of Chhuzom, altitude 2,043 m a.s.l., dry W-facing slope, $27^{\circ} 15.40^{\prime} \mathrm{N}, 89^{\circ} 31.70^{\prime} \mathrm{E}$, EGCGPL 20.10.2018 (NBCB1204); rocky S-slope $9 \mathrm{~km} \mathrm{SSW} \mathrm{of} \mathrm{Chhuzom,}$ altitude $2,450 \mathrm{~m}$ a.s.1., $27^{\circ} 14^{\prime} \mathrm{N}, 89^{\circ} 30^{\prime} \mathrm{E}$, EGPL 07.04.2013 (NBCB1154); rocky S-slope $12 \mathrm{~km}$ SSW of Chhuzom, altitude 2,650 m a.s.1., $27^{\circ} 13^{\prime} \mathrm{N}$, $89^{\circ} 29^{\prime}$ E, EGPL 07.04.2013 (NBCB1155); small gully with high rockface at $\mathrm{N}$-side, altitude $2,150 \mathrm{~m}$ a.s.l., $27^{\circ} 18^{\prime} \mathrm{N}, 8^{\circ} 33^{\prime} \mathrm{E}$, EGPL 07.04.2013 (NBCB1156; RMNH.MOL.346816); S of Paro (= Rinpung) Dzong, E-side river, altitude $2,250 \mathrm{~m}$ a.s.l., $27^{\circ} 25^{\prime} \mathrm{N}, 89^{\circ} 25^{\prime} \mathrm{E}$, EGPL 11.04.2013 (NBCB1157); $8 \mathrm{~km} \mathrm{SW}$ of Paro near Dzongdrakha, altitude $2,530 \mathrm{~m}$ a.s.l., $27^{\circ} 23^{\prime} \mathrm{N}$, $89^{\circ} 24^{\prime} \mathrm{E}$, EGPL 11.04.2013 (NBCB1158). District Thimphu: road to quarry near Bjimina, $13 \mathrm{~km} \mathrm{SW}$ of Thimphu, altitude $2,300 \mathrm{~m}$ a.s.1., $27^{\circ} 24^{\prime} \mathrm{N}, 89^{\circ} 34^{\prime} \mathrm{E}$, EG 16.06.2012 (NBCB1159; RMNH.MOL.346817); $16 \mathrm{~km} \mathrm{SSW}$ of Thimphu, $3 \mathrm{~km} \mathrm{~N}$ of bridge, altitude 2,100 m a.s.1., $27^{\circ} 20^{\prime} \mathrm{N}, 89^{\circ} 34^{\prime} \mathrm{E}$, EGPL 6.04.2013 (NBCB1160); $2 \mathrm{~km} \mathrm{~S}$ of Thimphu, altitude 2,350 m a.s.l., barren S-exposed slope, $27^{\circ} 26.35^{\prime} \mathrm{N}, 89^{\circ} 39.15^{\prime} \mathrm{E}$, EGCGPL 20.10.2018 (NBCB 1194).

Description. The greyish white, slightly transparent shell is cylindro-ovoid to subcylindrical; it has $4 \frac{3}{4}$ convex whorls with irregular growth lines. The last whorl is obliquely flattened and has a slight indentation, corresponding with the position of the palatalis inferior inside the aperture; the umbilicus is minute. The aperture is roundish, with a continuous, broadly reflected peristome, not protruding at the parietal side; there are (1) two columellar denticles, viz. a prominent columellaris and a smaller infracolumellaris, which is positioned near the transition to the basal side, (2) two or three palatal denticles, viz. a prominent palatalis inferior, a moderately prominent palatalis superior, and a rudimentary suprapalatalis, which may be lacking completely, and (3) at the parietal side, a parietalis that is fused with the little smaller angularis into a parieto-angularis, and often a small infraparietalis.

Measurements $(\mathrm{n}=18)$. H 1.97-2.41 mm, W 1.03$1.07 \mathrm{~mm}$.

Distribution. According to RAMAKRISHNA et al. (2010: 123), G. huttoniana occurs in northern India (Himachal Pradesh, Kashmir) and central western India (Maharashtra). POKRYSZKO et al. (2009: 435) 
reported many records for Pakistan. BÖSSNECK \& MENG (2018: 135) indicated occurrences in western Nepal, at altitudes of 1,680-3,400 m a.s.l. This species is known from three districts in western Bhutan, viz. Haa, Paro and Thimphu, where it was recorded at altitudes of 2,040-3,100 $\mathrm{m}$ a.s.l.

\section{Genus Bensonella Pilsbry et Vanatta, 1900}

Type species: Pupa plicidens Benson, 1849, by original designation.

Note. Bensonella s. str. and Paraboysidia Pilsbry, 1917 are considered synonyms (see below).

\section{Bensonella plicidens (Benson, 1849)}

Figs 9-11, 19

Pupa plicidens BENSON (1849: 126), India, Uttarakhand, "Landour et Mussoorie".

Bensonella plicidens - BUDHA \& BACKELJAU (2017: 189, 197), GitTENBERGER et al. (2017: 55, fig. 40).

Material. District Pemagatshel, SW-side of Pemagatshel, altitude $1,700 \mathrm{~m}$ a.s.l., $27^{\circ} 02.70^{\prime} \mathrm{N}$, 9125.18'E, EGPL 15.04.2015 (NBCB1162).

Description (adapted after BUDHA \& BACKELJAU 2017). The light brown, conical shell has irregular, radial, vague riblets and growth lines; the umbilicus is narrow. The aperture is little higher than broad; it is broadly rounded basally. Inside the aperture there are 14-16 'lamellae', most of which are hooked; they vary considerably in length. The peristome is more or less clearly interrupted at the parietal side.

Measurements (after BUDHA \& BACKELJAU 2017: 198). H 2.0-2.5 mm, W 1.5-1.9 mm.

Distribution. This easily identifiable species (but see notes) is reported with two subspecies from a limited number of scattered localities, ranging from NW. India in the west to Japan and Taiwan in the east (Fig. 9). This geographic distribution is unusual because of the combination of localities that belong in different biogeographic areas, like Taiwan and Bhutan. We do not know a similar pattern from other molluscs. The only record for Bhutan is at an altitude of $1,700 \mathrm{~m}$ a.s.l. SW of Pemagatshel in the district of that name. Notes. Only one fragile shell was found. This vulnerable specimen was not used for photographs. It has the conspicuous claw-like apertural 'lamellae', which are considered diagnostic for this species. However, BUDHA \& BACKELJAU (2017: 197) suggested that the hooked lamellae might not even be a species specific character state since in many samples labelled as this species the lamellae are simple, not hooked. They further hypothesized that there has been a "mixture of hooked and non-hooked shells in Benson's collection". It remains to investigate then whether there are additional differences between these two categories of shells. Sub-adult specimens could be studied to learn

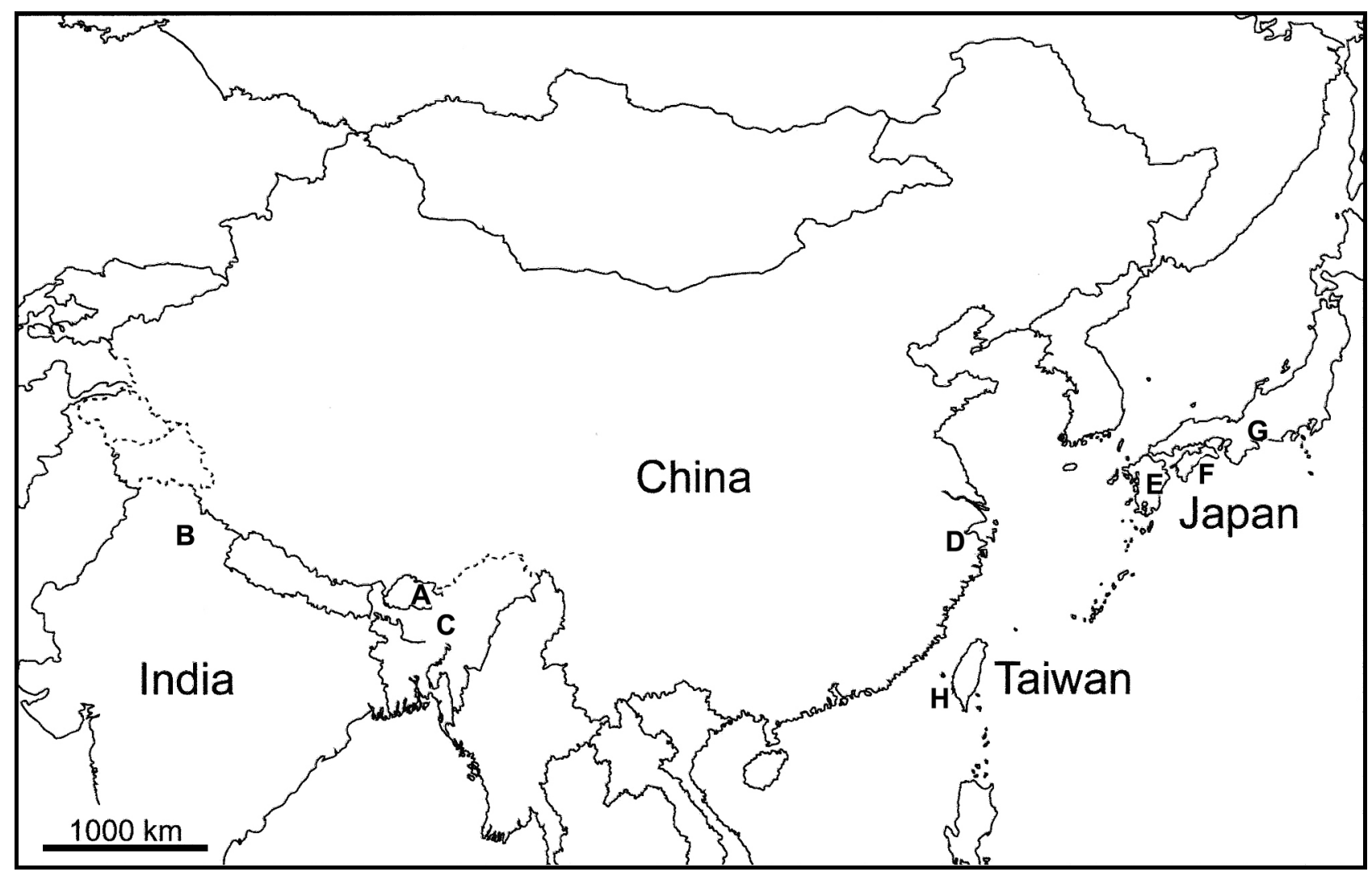

Fig. 9. Records of Bensonella plicidens (Benson, 1849) s.l., after HwANG (2014), adapted: (A) Bhutan, (B) India, Uttar Pradesh, Landour and Mussoorie, (C) India, Assam, Khasi Hills, (D) E China, (E-G) Japan, (H) Taiwan 


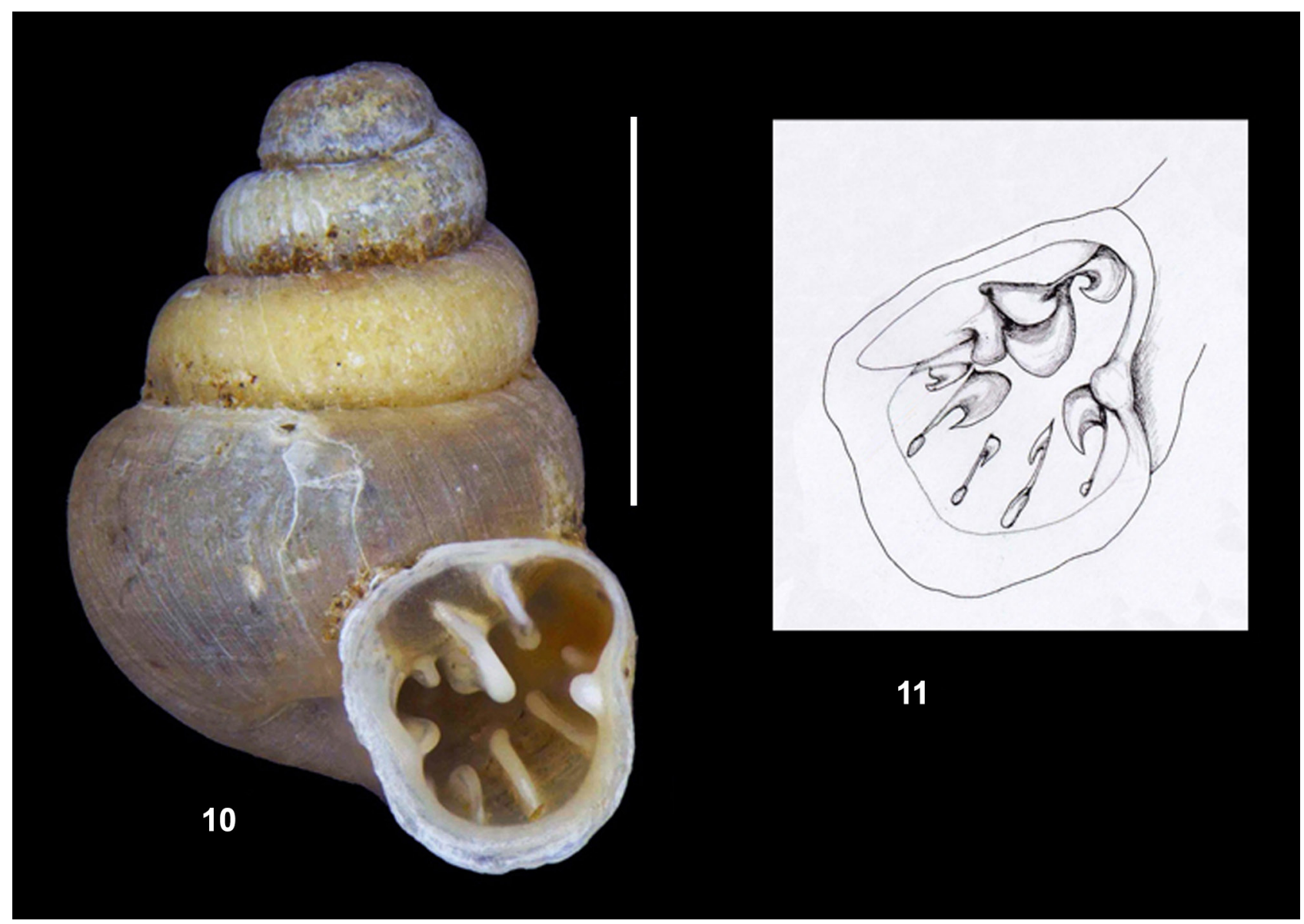

Figs 10-11. Bensonella plicidens (Benson, 1849) s.1.: 10 - B. p. plicidens, syntype (UMZC I.102325), India, Uttar Pradesh, Landour (after BUDHA \& BACKELJAU 2017: 198, fig. 5A), 11 - B. p. lakainguta Hwang, 2014, drawing of the claw-like apertural armature (after HWANG 2014: fig. 4A)

how the apertural lamellae are formed. The simple lamellae might represent an intermediate stage that is followed occasionally by partial dissolving of the lamellae, eventually resulting in the apertural claws. Secondary dissolving apertural lamellae are known from Pupilloidea like Orcula species (ZILCH 1959: 155, GITTENBERGER 1983: 331; 1996: 198).

WADA \& CHIBA (2013) demonstrated experimentally that the apertural barriers in this species are functional against predators.

\section{Family Valloniidae Morse, 1864}

\section{Subfamily Valloniinae Morse, 1864}

\section{Genus Vallonia Risso, 1826}

Type species: Vallonia rosalia Risso, 1826 [= Vallonia pulchella (Müller, 1774)], by monotypy. See Opinion 335 (HEMMING 1955: 50).

\section{Vallonia costohimala Gerber et Bössneck, 2009}

\section{Figs 12-16}

Vallonia costohimala GERBER \& BÖSSNECK (2009: 45,

51), Nepal, "Sagamartha Zone, Solukhumbu
District, Khumuche-Himal range, $27^{\circ} 52.90^{\prime} \mathrm{N}$, 86²3.87'E", 4,090-4,180 m a.s.1., "S-facing slope”, GiTTENBERGER et al. (2017: 51, fig. 36), BUDHA et al. (2015: 10; 2017: 25).

Material. District Haa: $4 \mathrm{~km} \mathrm{NW}$ of Haa, altitude 2,985 m a.s.1., $27^{\circ} 23^{\prime} \mathrm{N}, 8^{\circ} 16^{\prime} \mathrm{E}$, EGPL 30.03.2016 (NBCB1195); $15 \mathrm{~km}$ WSW of Paro, altitude 3,100 $\mathrm{m}$ a.s.1., $\quad 27^{\circ} 22^{\prime} \mathrm{N}, \quad 8^{\circ} 17^{\prime} \mathrm{E}$, EGPL 30.03.2016 (NBCB1196). District Paro: 14 km SE of Paro, N-side river, near monastery Tachugang Lhakhang, altitude 2,150 $\mathrm{m}$ a.s.1., among rocks near small rockface, $27^{\circ} 20^{\prime} \mathrm{N}, 8^{\circ} 30^{\prime} \mathrm{E}, \mathrm{EGPL}$ 06.04.2013 (NBCB1123; RMNH.MOL.346818); $6.5 \mathrm{~km} \mathrm{~S}$ of Chhuzom, altitude 2,043 $\mathrm{m}$ a.s.1., dry W-facing slope, $27^{\circ} 15.40^{\prime} \mathrm{N}$, 89³1.70'E, EGCGPL 20.10.2018 (NBCB1197); rocky S-slope $9 \mathrm{~km}$ SSW of Chhuzom, altitude 2,450 m a.s.1., $27^{\circ} 14^{\prime} \mathrm{N}, 8^{\circ} 30^{\prime} \mathrm{E}, \mathrm{EGPL} 07.04 .2013$ (NBCB1124); 10 $\mathrm{km} \mathrm{SW}$ of Chhuzom, altitude 2,500 $\mathrm{m}$ a.s.1., $27^{\circ} 14^{\prime} \mathrm{N}$ 89³0'E, EGPL 07.04.2013 (NBCB1125); small gully with high rockface at $\mathrm{N}$-side, altitude 2,150 $\mathrm{m}$ a.s.l., $27^{\circ} 18^{\prime} \mathrm{N}, 8^{\circ} 33^{\prime} \mathrm{E}, \mathrm{EGPL}$ 07.04.2013 (NBCB1126; RMNH.MOL.346819); S of Paro Dzong, E-side river, altitude $2,250 \mathrm{~m}$ a.s.1., $27^{\circ} 25^{\prime} \mathrm{N}, 89^{\circ} 25^{\prime} \mathrm{E}$, EGPL 11.04.2013 (NBCB1127; RMNH.MOL.346820); road 


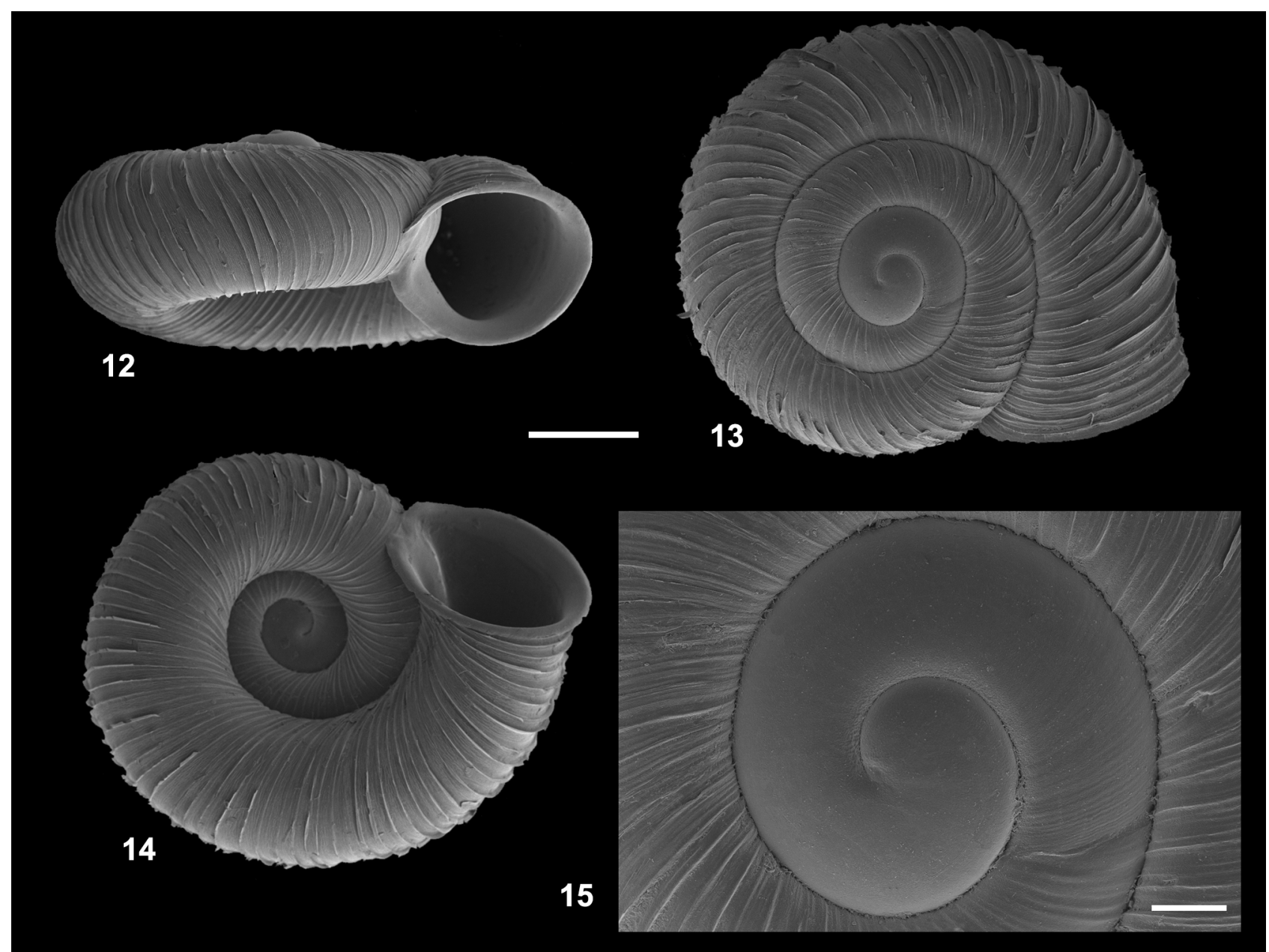

Figs 12-15. Vallonia costohimala Gerber et Bössneck, 2009 (NBCB1130), district Thimphu, road to quarry near Bjimina, 13 km SW of Thimphu, altitude 2,300 m a.s.l., shells (W): $12-2.43 \mathrm{~mm}, 13-2.32 \mathrm{~mm}, 14-2.29 \mathrm{~mm} ; 15$ - protoconch sculpture. Scale bars $0.5 \mathrm{~mm}(12-14), 100 \mu \mathrm{m}$ (15)

Paro - Haa, altitude 2,250 m a.s.1., $27^{\circ} 23^{\prime} \mathrm{N}, 89^{\circ} 26^{\prime} \mathrm{E}$, EGPL 11.04.2013 (NBCB1128); 8 km SW Paro near Dzongdrakha, altitude 2,530 m a.s.l., $27^{\circ} 23^{\prime} \mathrm{N}$, 89²4'E, EGPL 11.04.2013 (NBCB1129). District Thimphu: road to quarry near Bjimina, $13 \mathrm{~km}$ SW of Thimphu, altitude 2,300 $\mathrm{m}$ a.s.1., $27^{\circ} 24^{\prime} \mathrm{N}, 8^{\circ} 34^{\prime} \mathrm{E}$, EG 16.06.2012 (NBCB1130; RMNH.MOL.346821).

Description. The fragile, whitish shell is discoid, with a low conical spire that is hardly visible in frontal view. The protoconch of $1 \frac{1}{8}$ whorls is smooth. The following, little more than 2 teleoconch whorls, have thin radial ribs that are heightened by periostracal lamellae; in between the ribs, the periostracum forms an irregular pattern of interconnected, roughly radially oriented line fragments and even smaller wrinkled ridges. There are 55-72 $(n=15)$ main ribs on the last whorl. The edge of the roundish aperture is narrowly reflected but not thickened and shortly interrupted without a callous thickening; its upper palatal side descends to about the periphery of the shell or little lower. The elliptical umbilicus measures nearly $40 \% \mathrm{~W}$.
Measurements $(\mathrm{n}=15)$. H 0.95-1.22 mm; W 2.10$2.57 \mathrm{~mm}$; U 2.7-3.0 mm.

Distribution. This species was described as endemic for northern Nepal, where it was found in "open, grassy habitats, such as alpine meadows, glacial moraines, talus slopes" at 3,550-4,830 m a.s.l. altitude (GERBER \& BÖSSNECK 2009: 46). All the records in western Bhutan, in the districts of Haa, Paro and Thimphu, are situated at lower altitudes, i.e. 2,040$3,100 \mathrm{~m}$ a.s.1., in rocky habitats at the foot of rockfaces, below the timber-line. This difference in the altitudes might be indicative of differential activities of malacologists instead of being ecologically relevant.

Notes. For additional data on this and other Himalayan Vallonia species, see GERBER \& BÖSSNECK (2009).

\section{Subfamily Acanthinulinae Steenberg, 1917}

\section{Genus Pupisoma Stoliczka, 1873}

Type species: Pupa lignicola Stoliczka, 1871, by original designation. 


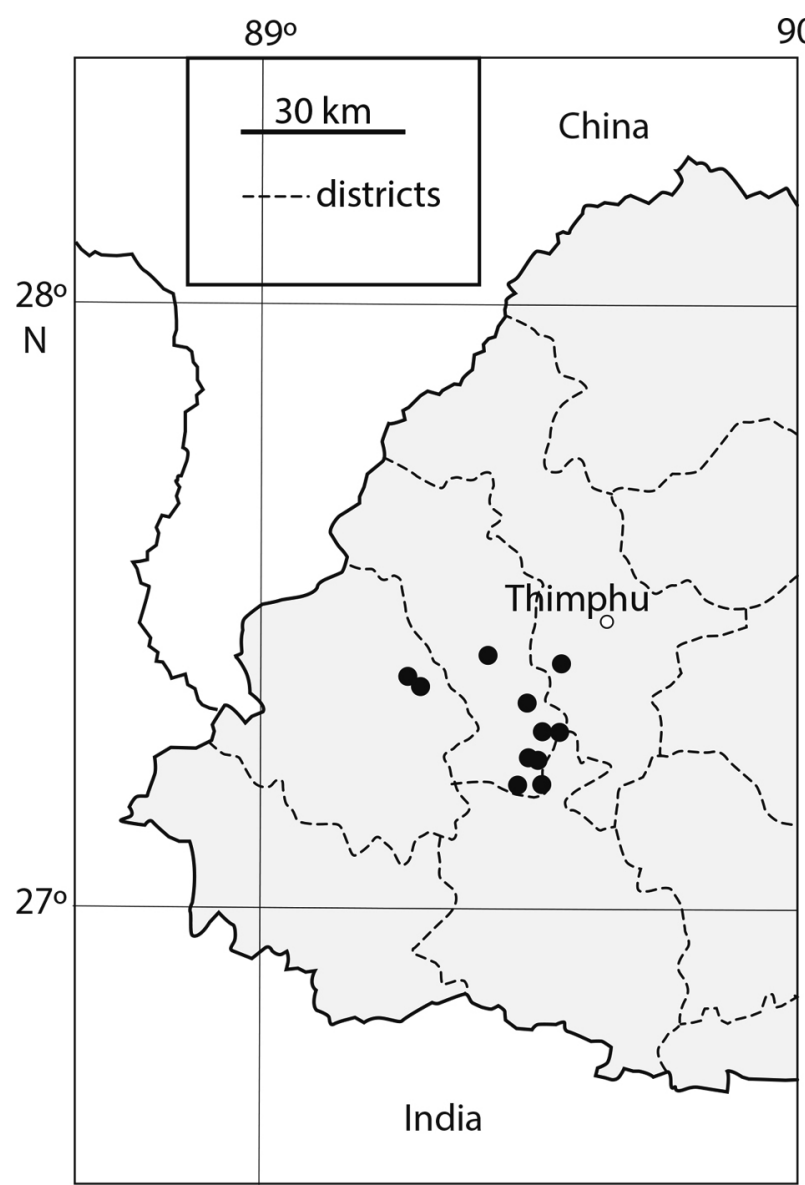

Fig. 16. Records of Vallonia costohimala Gerber et Bössneck, 2009

Pupisoma paroense Gittenberger et Leda, n. sp. Figs 17-19

Pupisoma spec. GitTENBERGER et al. (2017: 52, fig. 37). Material. District Paro: small gully with high rockface at $\mathrm{N}$-side, altitude $2,150 \mathrm{~m}$ a.s.l., $27^{\circ} 18^{\prime} \mathrm{N}, 89^{\circ} 33^{\prime} \mathrm{E}$, EGPL 07.04.2013 (NBCB1131/holotype, 1132/3 paratypes; RMNH.MOL.346822/2 paratypes).

Diagnosis. Shell conical with slightly convex sides, less than $2 \mathrm{~mm}$ high, without spiral sculpture.

Description. The yellowish brown shell is conical with slightly convex sides; it has $33 / 4-4$ very convex whorls and a deeply incised suture. The protoconch is finely pustular. The teleoconch has a very fine wrinkly surface and narrowly spaced growth ridges that are most prominent near the suture, where they form papillae. The aperture is roundish, apart from the parietal side and the straight columellar border. The apertural edge is not thickened; it is reflected only at the columellar side, most broadly so at the attachment to the body whorl. The umbilicus is minute.

Measurements $(\mathrm{n}=6)$. H $1.7-1.9 \mathrm{~mm}, \mathrm{~W} 1.3-$ $1.5 \mathrm{~mm}$. Holotype: H $1.7 \mathrm{~mm}, \mathrm{~W} 1.3 \mathrm{~mm}$.

Distribution. This species is only known from the type-locality, at 2,150 $\mathrm{m}$ a.s.l. in the district of Paro in Bhutan.
Differentiation. Only two species of Pupisoma s. str., by definition with shells without spiral lines, are mentioned by Pilsbry (1920), viz. P. (P.) lignicola (Stoliczka, 1871) (PILSBRY 1920: pl. 2, figs 7, 10) from Myanmar and P. (P.) evezardi (Hanley et Theobald, 1874) (PILSBRY 1920: pl. 2, figs 8, 9; RAHEEM et al. 2014: 63, 183 fig. E) from the Western Ghats, India. They both differ in larger shells that have more convex sides in profile.

Without a subgeneric classification or description, RAMAKRISHNA et al. (2010: 125) doubtfully cited "Pupisoma seriola (Benson, 1863)" for India. The figure that was published by HANLEY \& THEOBALD (1874: pl. 101 fig. 8) is also inconclusive for that taxon. Pupa seriola was superficially described after two shells by BENSON (1863: 427) from (p. 428) "regione Orissae (Cuttack)", India. The measurements are indicated as $2 \frac{1}{2} \times 1 \frac{1}{3} \mathrm{~mm}$ and for one shell the presence of a parietal lamella in mentioned. These data are sufficient to conclude that the Pupisoma from Bhutan is a different species, with smaller shells without any denticle or lamella in the aperture.

Etymology. The neutral Greek noun 'soma' in Pupisoma goes with the epithet paroense, to refer to the occurrence in the district of Paro.

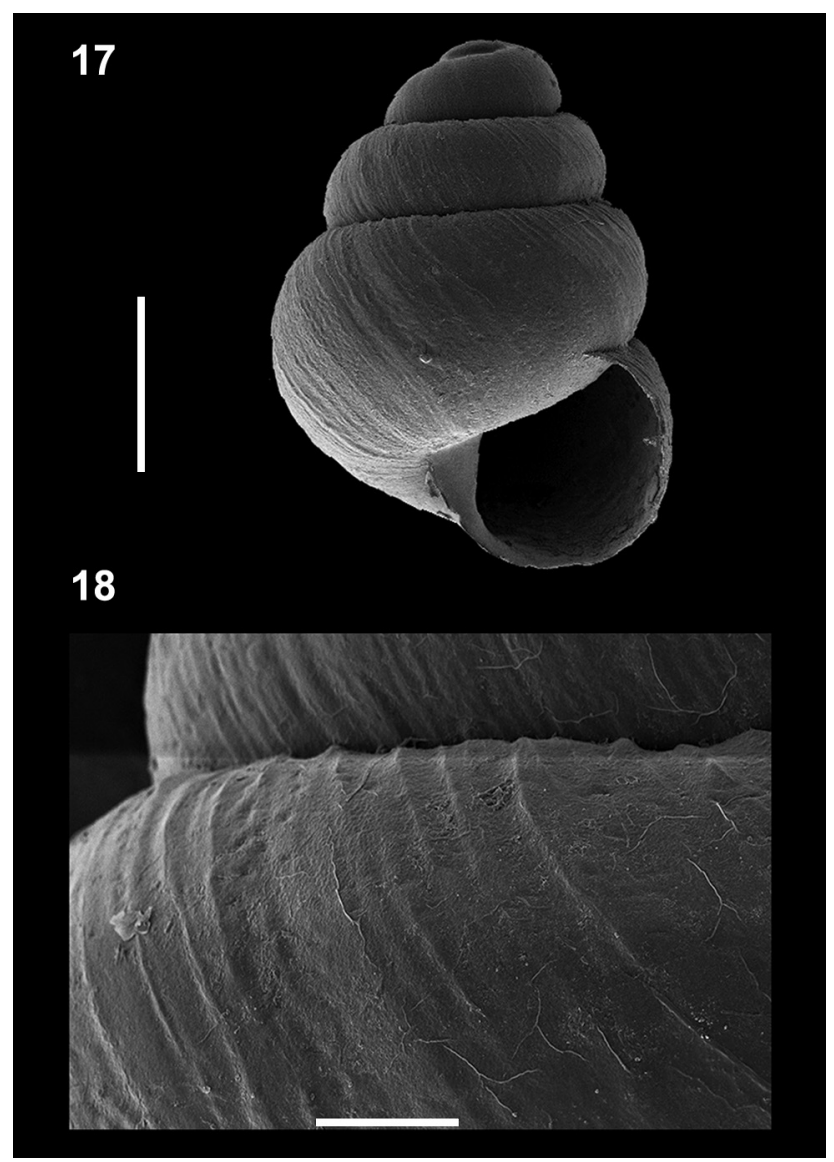

Figs 17-18. Pupisoma paroense Gittenberger et Leda, n. sp., holotype (NBCB1131), district Paro, small gully with high rockface at $\mathrm{N}$-side, altitude $2,150 \mathrm{~m}$ a.s.l., $\mathrm{H}$ $1.7 \mathrm{~mm}$. Scale bars $0.5 \mathrm{~mm}$ (17), $100 \mu \mathrm{m}$ (18) 


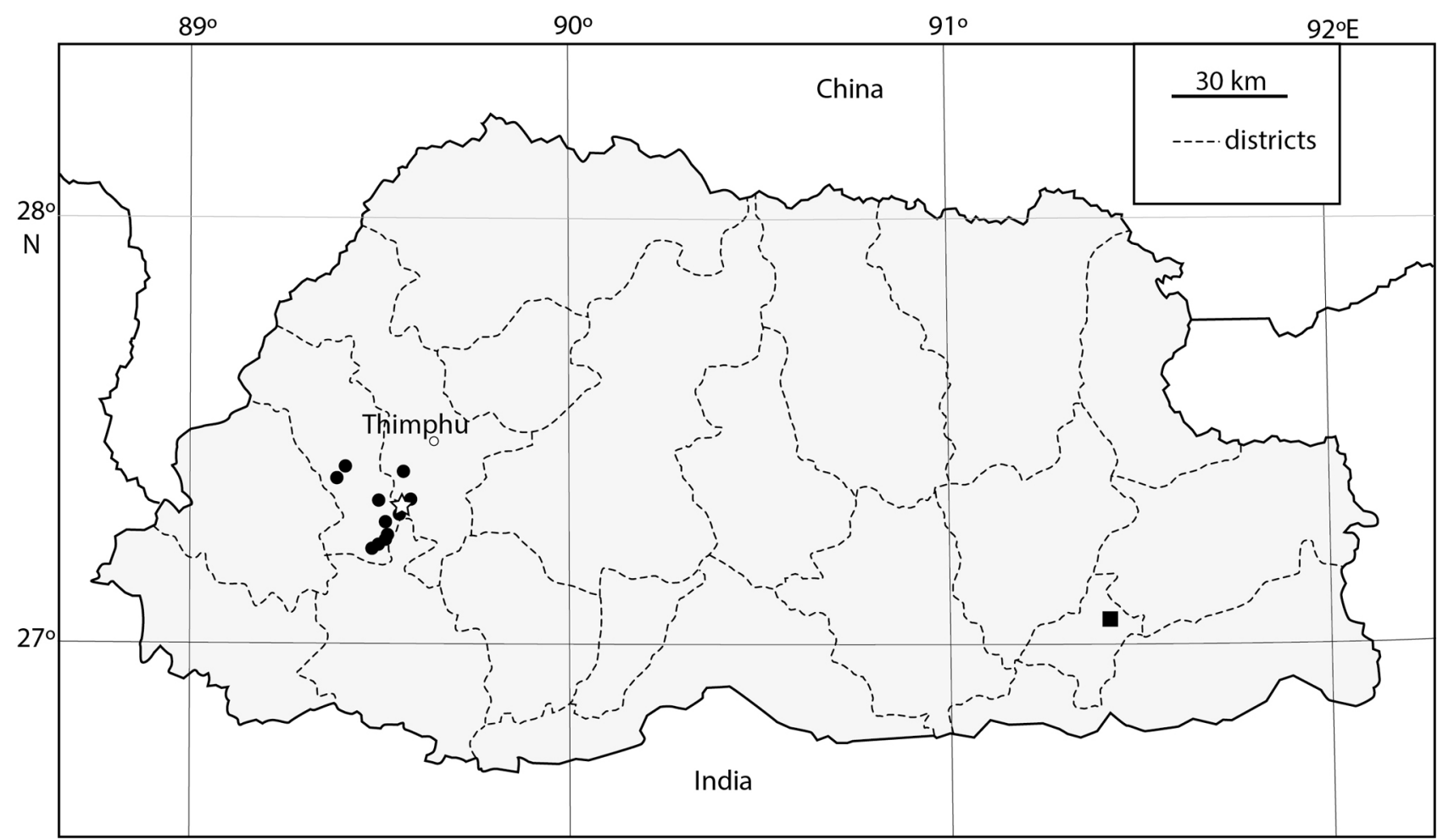

Fig. 19. Records of Bensonella plicidens (Benson, 1849) (square), Pupisoma paroense n. sp. (star), Truncatellina bhutanensis Gittenberger, Leda et Sherub, 2013 (dots)

\section{Family Truncatellinidae Steenberg, 1925}

Genus Truncatellina Lowe, 1852

Type species: Pupa linearis Lowe, 1852, by monotypy. See Opinion 335 (Hemming 1955: 50).

\section{Truncatellina bhutanensis Gittenberger, Leda et Sherub, 2013}

Figs 19-20

Truncatellina bhutanensis GITTENBERGER at al. (2013: 29, 30), Bhutan, district Paro, "S-slope E of limestone quarry NW of Dobji Dzong”, GITTENBERGER et al. (2017: 53, fig. 38).

Material. District Paro: $14 \mathrm{~km}$ SE of Paro, N-side river, near monastery Tachugang Lhakhang, altitude 2,150 $\mathrm{m}$ a.s.l., among rocks near small rockface, $27^{\circ} 20^{\prime} \mathrm{N}$, 89³0'E, EGPL 06.04.2013 (NBCB1002); S-slope E of limestone quarry NW of Dobji Dzong, altitude 2,300 $\mathrm{m}$ a.s.1., $27^{\circ} 17^{\prime} \mathrm{N}, 89^{\circ} 31^{\prime} \mathrm{E}$, EGPL 07.04.2013 (NBCB1003/holotype, 1004); $6.5 \mathrm{~km} \mathrm{~S}$ of Chhuzom, altitude 2,043 m a.s.1., dry W-facing slope, $27^{\circ} 15.40^{\prime} \mathrm{N}, 89^{\circ} 31.70^{\prime} \mathrm{E}$, EGPL 20.10.2018 (NBCB1161); rocky S-slope $9 \mathrm{~km}$ SSW of Chhuzom, altitude 2,450 $\mathrm{m}$ a.s.1., $27^{\circ} 14^{\prime} \mathrm{N}, 89^{\circ} 30^{\prime} \mathrm{E}$, EGPL 07.04.2013 (NBCB1005); rocky S-slope $12 \mathrm{~km}$ SSW of Chhuzom, altitude 2,650 $\mathrm{m}$ a.s.1., $27^{\circ} 13^{\prime} \mathrm{N}$, 89²9'E, EGPL 07.04.2013 (NBCB1006); 10 km SW of Chhuzom, altitude 2,500 $\mathrm{m}$ a.s.1., $27^{\circ} 14^{\prime} \mathrm{N}, 89^{\circ} 30^{\prime} \mathrm{E}$, EGPL 07.04.2013(NBCB1007); small gully with high rockface at $\mathrm{N}$-side, altitude $2,150 \mathrm{~m}$ a.s.1., $27^{\circ} 18^{\prime} \mathrm{N}$,

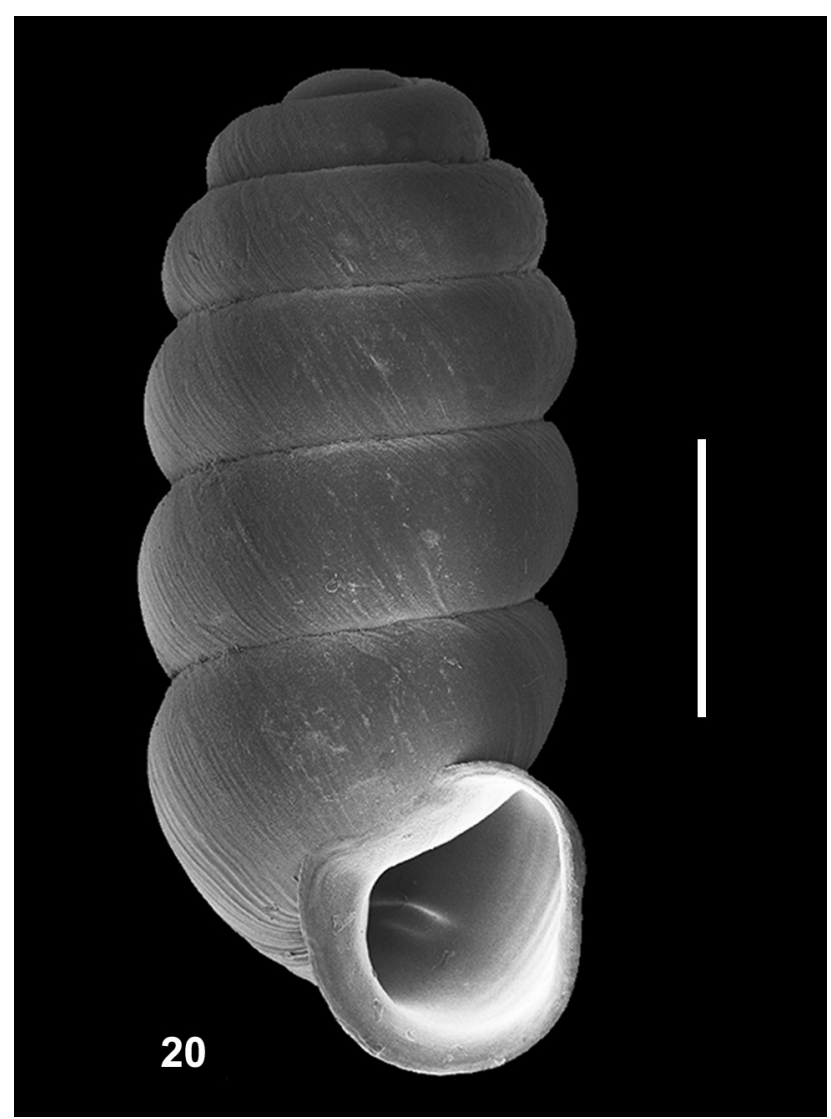

Fig. 20. Truncatellina bhutanensis Gittenberger, Leda et Sherub, 2013, holotype (NBCB1003), district Paro, S-slope E of limestone quarry NW of Dobji Dzong, altitude 2,300 m a.s.l., H $1.84 \mathrm{~mm}$. Scale bar $0.5 \mathrm{~mm}$ 
89³3'E, EGPL 07.04.2013 (NBCB1008); S of Paro Dzong, E-side river, altitude 2,250 $\mathrm{m}$ a.s.l., $27^{\circ} 25^{\prime} \mathrm{N}$, $89^{\circ} 25^{\prime}$ E, EGPL 11.04.2013 (NBCB1009); 8 km SW Paro near Dzongdrakha, altitude 2,530 $\mathrm{m}$ a.s.l., $27^{\circ} 23^{\prime} \mathrm{N}, 8^{\circ} 24^{\prime} \mathrm{E}$, EGPL 11.04.2013 (NBCB1010). District Thimphu: road to quarry near Bjimina, $13 \mathrm{~km}$ SW of Thimphu, altitude $2,300 \mathrm{~m}$ a.s.l., $27^{\circ} 24^{\prime} \mathrm{N}$, $89^{\circ} 34^{\prime} \mathrm{E}, \quad \mathrm{EG}$ 16.06.2012 (NBCB1000; RMNH. MOL.346823); $16 \mathrm{~km} \mathrm{SSW} \mathrm{of} \mathrm{Thimphu,} 3 \mathrm{~km} \mathrm{~N}$ of bridge, altitude $2,100 \mathrm{~m}$ a.s.1., $27^{\circ} 20^{\prime} \mathrm{N}, 89^{\circ} 34^{\prime} \mathrm{E}$, EGPL 06.04.2013 (NBCB1001).

Description. The fragile, light brown, rather glossy shell is cylindrical with a domed apical part; it has $53 / 4$ convex whorls, which are separated by a deeply incised suture. The protoconch has a very finely pitted, nearly smooth surface; the teleoconch has relatively coarse growth lines, some of which may be thickened as riblets near the aperture. The umbilicus is minute. The squarish aperture is somewhat higher than broad; it has a narrowly reflected, slightly thickened apertural lip. Inside the aperture there is only a prominent or, rarely, obsolete, palatal denticle, which is visible in frontal view; in some shells there is an inconspicuous columellar denticle, which is only discernible in very oblique view.

Measurements $(\mathrm{n}=50)$. H 1.4-1.85 mm, W 0.75$0.85 \mathrm{~mm}$.

Distribution. This species is hitherto known only from the districts of Paro and Thimphu in western Bhutan, where it was recorded at altitudes of 2,040$2,650 \mathrm{~m}$ a.s.l. The identity of "Truncatellina sp." from western Nepal (KUZNETSOV \& SCHILEYKO 1997: 135), the only record for Truncatellina in Nepal, is still unknown.

\section{Family Enidae B. B. Woodward, 1903}

\section{Genus Pseudonapaeus Westerlund, 1887}

Type species: Buliminus asiaticus von Martens, 1880, by subsequent designation (LINDHOLM 1922: 274). See LindHOLM (1925: 28) and BANK \& NEUBERT (1998: 82).

\section{Pseudonapaeus occibhutanus Gittenberger, Gyeltshen et Sherub, n. sp.}

Figs 21-29

Subzebrinus spec. GitTENBERGER et al. (2017: 56, fig. 41).

Type series. Holotype (NBCB1205), district Thimphu, road to quarry near Bjimina, $13 \mathrm{~km} \mathrm{SW}$ of Thimphu, altitude $2,300 \mathrm{~m}$ a.s.l., $27^{\circ} 24^{\prime} \mathrm{N}, 89^{\circ} 34^{\prime} \mathrm{E}$, EG 16.06.2012.

Paratypes. District Paro: $14 \mathrm{~km}$ SE of Paro, N-side river, near monastery Tachugang Lhakhang, altitude 2,150 $\mathrm{m}$ a.s.l., among rocks near small rockface, $27^{\circ} 20^{\prime} \mathrm{N}, 8^{\circ} 30^{\prime} \mathrm{E}$, EGPL 06.04.2013 (NBCB1136/5);
$20 \mathrm{~km}$ SSE of Paro, altitude 2,325 m a.s.1., $27^{\circ} 16^{\prime} \mathrm{N}$, 89³1'E, EGPL 31.03.2016 (NBCB1207/12); $4.5 \mathrm{~km}$ SW of Paro, Khangkhu, altitude 2,339 m a.s.l., $27^{\circ} 24^{\prime} \mathrm{N}$ $89^{\circ} 24^{\prime} \mathrm{E}$, Sherub leg. 10.05.2015 (NBCB1211/12); $26 \mathrm{~km} \mathrm{SW}$ of Paro, altitude 2,485 m a.s.l., $27^{\circ} 12^{\prime} \mathrm{N}$, $89^{\circ} 29^{\prime} \mathrm{E}$, EGPL 31.03.2016 (NBCB1206/4); $21 \mathrm{~km}$ SE of Paro, altitude $2,160 \mathrm{~m}$ a.s.l., $27^{\circ} 18^{\prime} \mathrm{N}, 89^{\circ} 32^{\prime} \mathrm{E}$, EGPL 31.03.2016 (NBCB1208/6); $6.5 \mathrm{~km} \mathrm{~S}$ of Chhuzom, altitude 2,043 m a.s.l., dry W-facing slope, $27^{\circ} 15.40^{\prime} \mathrm{N}, 89^{\circ} 31.70^{\prime} \mathrm{E}$, EGCGPL 20.10 .2018 (NBCB2610/4); S-slope E of limestone quarry NW of Dobji Dzong, altitude 2,300 $\mathrm{m}$ a.s.1., $27^{\circ} 17^{\prime} \mathrm{N}, 89^{\circ} 31^{\prime} \mathrm{E}$, EGPL 07.04.2013 (NBCB1137/5); rocky S-slope 9 km SSW of Chhuzom, $2,450 \mathrm{~m}$ a.s.1., $27^{\circ} 14^{\prime} \mathrm{N}, 89^{\circ} 30^{\prime} \mathrm{E}$, EGPL 07.04.2013 (NBCB1138/2); rocky S-slope $12 \mathrm{~km}$ SSW of Chhuzom, altitude 2,650 m a.s.l., $27^{\circ} 13^{\prime} \mathrm{N}, 8^{\circ} 29^{\prime} \mathrm{E}, \mathrm{EGPL}$ 07.04.2013 (NBCB1139/1); $10 \mathrm{~km}$ SW Chhuzom, altitude 2,500 m a.s.1., $27^{\circ} 14^{\prime} \mathrm{N}$, 89³0'E, EGPL 07.04.2013 (NBCB1140/2); small gully with high rockface at $\mathrm{N}$-side, altitude $2,150 \mathrm{~m}$ a.s.l., $27^{\circ} 18^{\prime} \mathrm{N}, 8^{\circ} 33^{\prime} \mathrm{E}$, EGPL 07.04.2013 (NBCB1141/4); road Paro - Haa, altitude 2,250 m a.s.l., $27^{\circ} 23^{\prime} \mathrm{N}$, $89^{\circ} 26^{\prime}$ E, EGPL 11.04.2013 (NBCB1142/9); S of Paro Dzong, E-side river, altitude 2,250 m a.s.l., $27^{\circ} 25^{\prime} \mathrm{N}$, $89^{\circ} 25^{\prime} \mathrm{E}$, EGPL 11.04.2013 (NBCB1143/2). District Thimphu: same data as holotype (NBCB1133/26; RMNH.MOL.346824/9, 346825/3 animals and 2 radulae in ethanol $70 \%$, genital slides $1189 \mathrm{a}-\mathrm{c}$ ); $2 \mathrm{~km} \mathrm{~S}$ of Thimphu, altitude 2,350 m a.s.l., barren S-exposed slope, $27^{\circ} 26.35^{\prime} \mathrm{N}, 89^{\circ} 39.15^{\prime} \mathrm{E}$, EGCGPL 20.10.2018 (NBCB1209/3); $3 \mathrm{~km}$ SE of Thimphu, Lungtenphu, altitude $2,300 \mathrm{~m}$ a.s.1., $27^{\circ} 27^{\prime} \mathrm{N}, 89^{\circ} 40^{\prime} \mathrm{E}$, H.R. FEIJEN leg. 15.08.1999 (RMNH.MOL71817/2, $346826 / 1$ animal in ethanol $70 \%$ ); $16 \mathrm{~km} \mathrm{SSW}$ of Thimphu, $3 \mathrm{~km} \mathrm{~N}$ of bridge, altitude 2,100 $\mathrm{m}$ a.s.l., $27^{\circ} 20^{\prime} \mathrm{N}, 8^{\circ} 34^{\prime} \mathrm{E}$, EGPL 6.04.2013 (NBCB1134/1); W of Geneykha (2.5 km E of Chhuzom), altitude 2,825 m a.s.l., $27^{\circ} 18^{\prime} \mathrm{N}, 8^{\circ} 35^{\prime} \mathrm{E}$, EG 16.06.2012 (NBCB1135/1).

Diagnosis. Shell thin, ovoid-conical, with spiral striae and a colour pattern of oblique irregular streaks. Description. The shell is relatively thin and ovoid-conical, with slightly convex whorls, separated by an incised suture. The apical part is light yellowish brown; most of the shell has brownish, very irregular streaks in the direction of the growth lines and spots, alternating with lighter parts. The protoconch has $1 \frac{1}{2}$ whorls and is smooth. The 5-51/2 teleoconch whorls have dense irregular growth lines, crossed by relatively prominent dense spiral lirae. The aperture is higher than broad, measuring ca. $40 \% \mathrm{H}$; its columellar edge is straight and runs parallel to the middle part of the palatal edge that gradually passes into the basal edge. The whitish apertural lip is somewhat thickened and expanded but not reflected, except for the columellar part in front of the narrowly open umbilicus. There is hardly any parietal callus. 
Measurements $(\mathrm{n}=35)$. H 13.6-17.5 mm; W 6.3$6.8 \mathrm{~mm}$

Genital tract (Figs 26-28). The most proximal part of the penis is little narrower than the basal part (A1) of the penial appendix which inserts close to the genital atrium. The penis gradually narrows considerably towards the attachment of the retractor muscle shortly before the transition to the proximal part (e1) of the epiphallus, which is $2-3$ times as broad and contains an elongated papilla. The short following part (e2) is nearly as narrow as the distal ending of the penis and connects to the relatively long and broad part (e3) that ends distally with a small caecum after which an equally broad part (e4) follows, ending with a short but prominent flagellum (f). The vas deferens (vd) inserts laterally to the epiphallus. The penial retractor muscle (rp) and the appendix retractor muscle (ra) insert separately on the diaphragm.

The basal part of the penial appendix (a1) has a lumen with a dense transverse structure, it is as broad as the longest segment (e3-4) of the epiphallus and half as long. A short globular part (a2), near the attachment of the separate retractor muscle, is followed by a twice as long cylindrical part with a

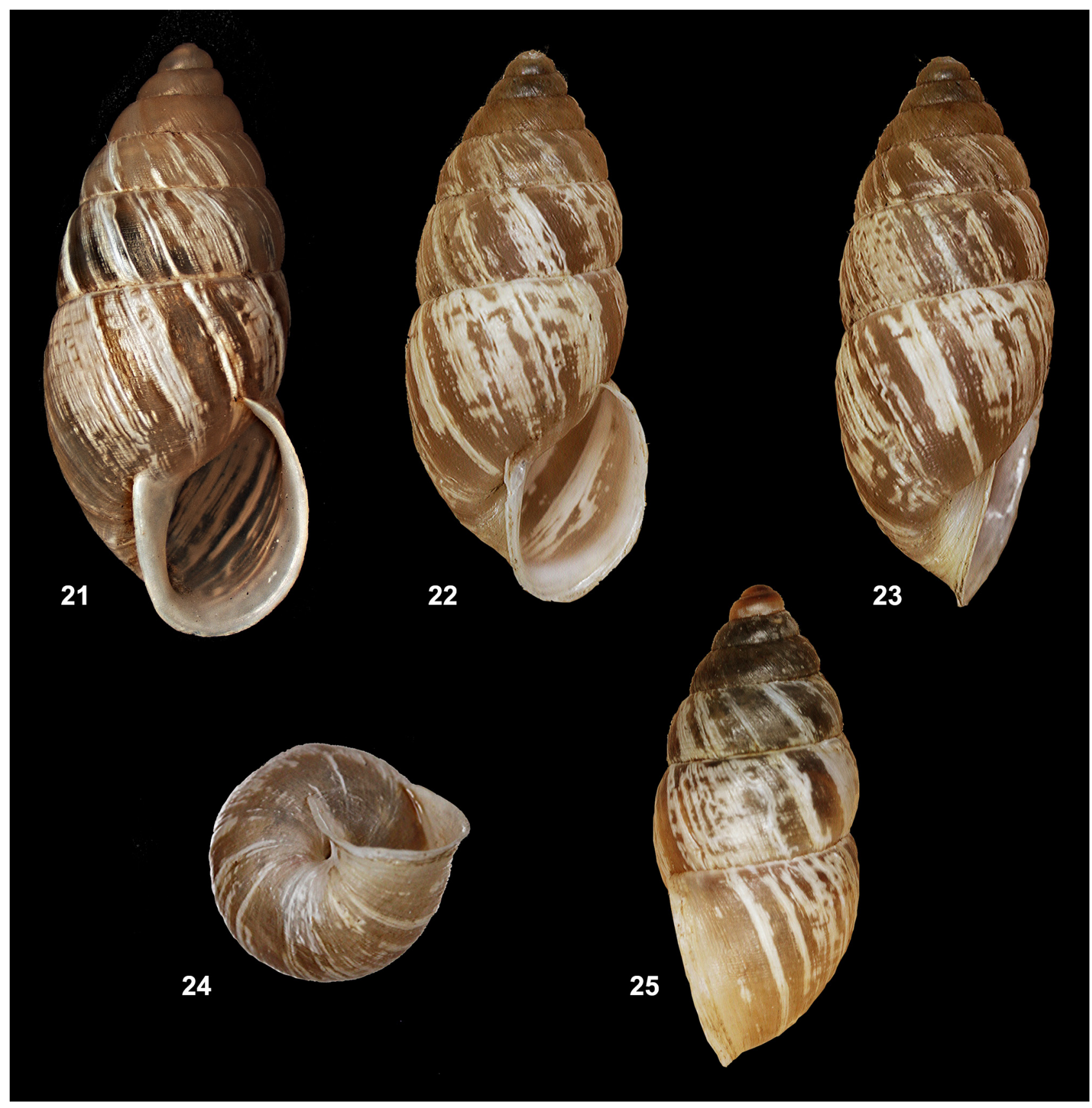

Figs 21-25. Pseudonapaeus occibhutanus Gittenberger, Gyeltshen et Sherub, n. sp.: 21 - holotype (NBCB1205), district Thimphu, road to quarry near Bjimina, $13 \mathrm{~km}$ SW of Thimphu, altitude 2,300 m a.s.1., H 17.4 mm; 22-25 - paratypes (NBCB1133a-b): H 16.0 mm (22-23), H 14.1 mm (24-25) 

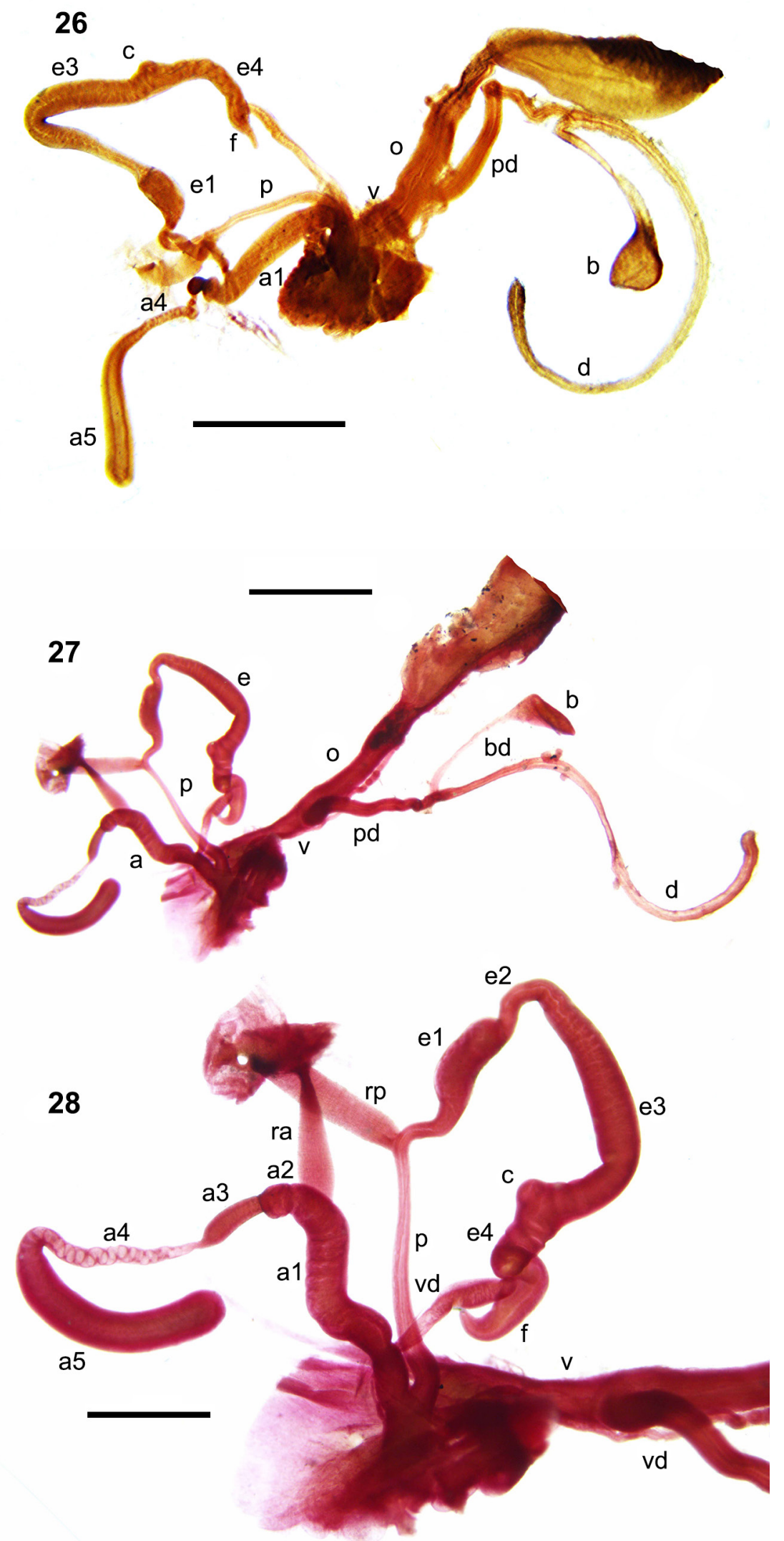

Figs 26-28. Pseudonapaeus occibhutanus Gittenberger, Gyeltshen et Sherub, n. sp., genital tracts: 26 - genital slide RMNH. MOL.1189a; 27 - RMNH.MOL.1189c); 28 - penial appendix in detail. District Thimphu, road to quarry near Bjimina, $13 \mathrm{~km} \mathrm{SW}$ of Thimphu, altitude 2,300 m a.s.l. Abbreviations: a - penial appendix, b - bursa of the bursa copulatrix, $\mathrm{c}$ - caecum, $\mathrm{d}$ - diverticulum, e - epiphallus, $\mathrm{f}$ - flagellum, o - oviductus, $\mathrm{p}$ - penis, pd - pedunculus of the bursa copulatrix, ra - appendix retractor muscle, $\mathrm{rp}$ - penial retractor muscle, $\mathrm{v}$ - vagina, $\mathrm{vd}$ - vas deferens 
thick wall and an unclear luminal structure that is half as broad (a3). Starting much narrower, the next part (a4), with a thin wall and a meandering luminal structure, very gradually increases in width towards the prominent bursa (a5) that is as long and broad as the basal part (a1). The vagina (v) is somewhat shorter than the penis (p), little broader than the epiphallus (e) and about as long as the oviductus (o). The pedunculus (pd) of the bursa copulatrix is as long as the bursa duct (bd), ending with an oval bursa (b), and twice as broad; it measures $1 / 4-1 / 5$ of the length of the diverticulum (d).

Differentiation. The poorly known Pseudonapaeus coelebs (L. Pfeiffer, 1846) from the western Himalaya in NW India (Kashmir, Uttarakhand) (GUDE 1914: 250) does not clearly differ in shell characters; data regarding its genital tract are not known. Photographs of two shells, kindly put at our disposal by Dr Bank, show that only the aperture might be less high $(37 \% \mathrm{H})$ in P. coelebs. More convincingly against the use of that name for the Bhutanese species are the distributional gap of over $1,000 \mathrm{~km}$ between the two ranges, and notes by THEOBALD (1878: 145) on $P$. coelebs, which is considered by the author "a forest species", very variable in size and form, "ranging from $22 \times 8$ to $14 \times 6.2 \mathrm{~mm}$ ". Live P. occibhutanus was

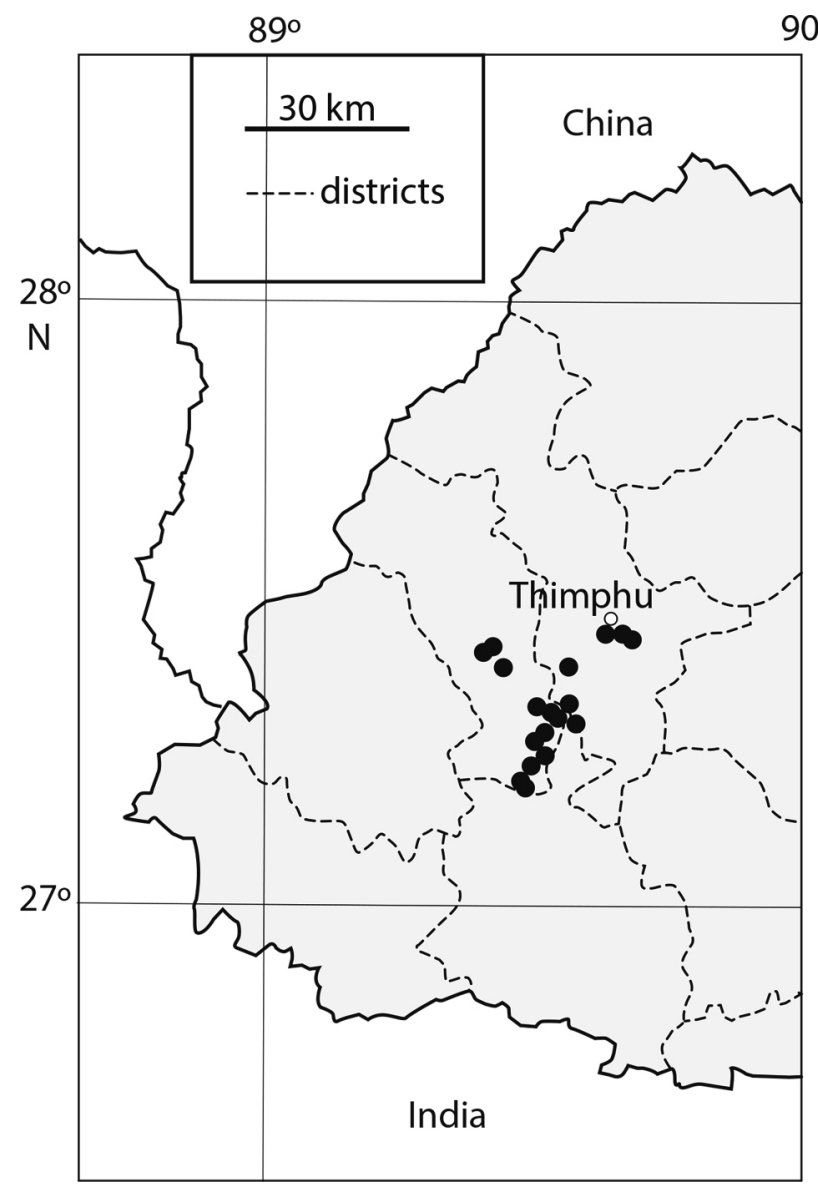

Fig. 29. Records of Pseudonapaeus occibhutanus Gittenberger, Gyeltshen et Sherub, n. sp. only found attached to bare limestone rock faces and the shells vary less in dimensions. Shells of $P$. sogdianus (E. von Martens, 1874), a species known from Iran, Turkmeniya, Uzbekistan and Kirgiziya, dealt with by SYSOEV \& SCHILEYKO (2009: 71, fig. 31E), SCHILEYKO \& RYMZHANOV (2013: 100, pl. 7, fig. K) and BANK \& NEUBERT (2016: 54, 55, pl. 20, figs 1-7) are also similar at first sight but are more solid, with a more prominent callus in the aperture and without spiral striae. P. tibetanus (L. Pfeiffer, 1857), according to Pfeiffer (1857: 331) from "Tibet", has a similar shape and colour pattern but a much larger shell ( $\mathrm{H}>30 \mathrm{~mm}$ ).

Distribution. This locally common species was recorded in western Bhutan, in the districts of Paro and Thimphu at altitudes of 2,040 and 2,825 $\mathrm{m}$ a.s.l. It was not observed in the district of Haa.

Etymology. The epithet occibhutanus refers to the occurrence in the western (L occidentalis) part of Bhutan, combined with bhutanus, going with the male generic name Pseudonapaeus.

\section{Genus Laevozebrinus Lindholm, 1925}

Type species: Bulimus urgutensis Kobelt, 1902, by original diagnosis.

\section{Laevozebrinus parvus Gittenberger, Gyeltshen et Leda, n. sp.}

Figs 30-34, 37-40

Laevozebrinus spec. GITTENBERGER et al. (2017: 57 fig. 42).

Type series. Holotype (NBCB1201), district Paro, $12 \mathrm{~km} \mathrm{SW}$ of Paro, altitude 3,680 m a.s.l., $27^{\circ} 22^{\prime} \mathrm{N}$, 89¹9'E, EGPL 30.03.2016.

Paratypes. District Chhukha: $11 \mathrm{~km} \mathrm{~S}$ of Chhuzom, altitude $2,330 \mathrm{~m}$ a.s.l., $27^{\circ} 12^{\prime} \mathrm{N}, \quad 89^{\circ} 32^{\prime} \mathrm{E}$, EGPL 08.04.2013 (NBCB1144/1). District Haa: 4 km NW of Haa, altitude $2,985 \mathrm{~m}$ a.s.l., $27^{\circ} 23^{\prime} \mathrm{N}, 89^{\circ} 16^{\prime} \mathrm{E}$, EGPL 30.03.2016 (NBCB1198/2); $15 \mathrm{~km}$ WSW of Paro, altitude 3,100 $\mathrm{m}$ a.s.l., $27^{\circ} 22^{\prime} \mathrm{N}, 8^{\circ} 17^{\prime} \mathrm{E}$; EGPL 30.03.2016 (NBCB1203/1). District Paro: same data as holotype (NBCB1202/1; RMNH.MOL.346827/2 animals in ethanol 70\% / genital slide 1188); $14 \mathrm{~km}$ SE of Paro, N-side river, near monastery Tachugang Lhakhang, altitude 2,150 $\mathrm{m}$ a.s.l., among rocks, near small rockface, $27^{\circ} 20^{\prime} \mathrm{N}, 89^{\circ} 30^{\prime} \mathrm{E}$, EGPL 6.04.2013 (NBCB1146/1); $26 \mathrm{~km} \mathrm{SW}$ of Paro, altitude 2,485 $\mathrm{m}$ a.s.1., $27^{\circ} 12^{\prime} \mathrm{N}, \quad 89^{\circ} 29^{\prime} \mathrm{E}, \quad$ EGPL 31.03.2016 (NBCB1199/3); S-slope E of limestone quarry NW of Dobji Dzong, 2,300 m a.s.l., $27^{\circ} 17^{\prime} \mathrm{N}, 89^{\circ} 31^{\prime} \mathrm{E}$, EGPL 07.04.2013 (NBCB1147/1; RMNH.MOL. genital slide 1186); $6.5 \mathrm{~km} \mathrm{~S}$ of Chhuzom, dry W-facing slope, altitude $2,043 \mathrm{~m}$ a.s.1., $27^{\circ} 15.40^{\prime} \mathrm{N}, 89^{\circ} 31.70^{\prime} \mathrm{E}$, EGCGPL 20.10.2018 (RMNH.MOL.346828/2); rocky S-slope $9 \mathrm{~km} \mathrm{SSW}$ of Chhuzom, altitude 2,450 m a.s.1., $27^{\circ} 14^{\prime} \mathrm{N}, 89^{\circ} 30^{\prime}$ E, EGPL 07.04.2013 
(NBCB1148/1; RMNH.MOL. genital slide 1187); $10 \mathrm{~km}$ SW Chhuzom, altitude 2,500 m a.s.1., $27^{\circ} 14^{\prime} \mathrm{N}, 8^{\circ} 30^{\prime} \mathrm{E}$, EGPL 07.04.2013 (NBCB1149/5); small gully with high rockface at $\mathrm{N}$-side, altitude 2,150 $\mathrm{m}$ a.s.1., $27^{\circ} 18^{\prime} \mathrm{N}, 8^{\circ} 33^{\prime} \mathrm{E}$, EGPL 07.04.2013 (NBCB1150/3; RMNH.MOL.346829/2); S of Paro Dzong, E-side river, altitude 2,250 $\mathrm{m}$ a.s.1., $27^{\circ} 25^{\prime} \mathrm{N}$, 89²5'E, EGPL 11.04.2013 (NBCB1151/6). District
Thimphu: road to quarry near Bjimina, $13 \mathrm{~km} \mathrm{SW}$ of Thimphu, altitude 2,300 $\mathrm{m}$ a.s.1., $27^{\circ} 24^{\prime} \mathrm{N}, 8^{\circ} 34^{\prime} \mathrm{E}$, EG 16.06.2012 (NBCB1145/17); W of Geneykha, 2.5 $\mathrm{km}$ E of Chhuzom, altitude $2,825 \mathrm{~m}$ a.s.1., $27^{\circ} 18.72 \mathrm{~N}$, 89³6.17'E, EG 16.06.2012 (NBCB1202/1).

Diagnosis. Shell less than $10 \mathrm{~mm}$ high, apertural lip poorly thickened and not reflected. Bursa copulatrix with diverticulum.
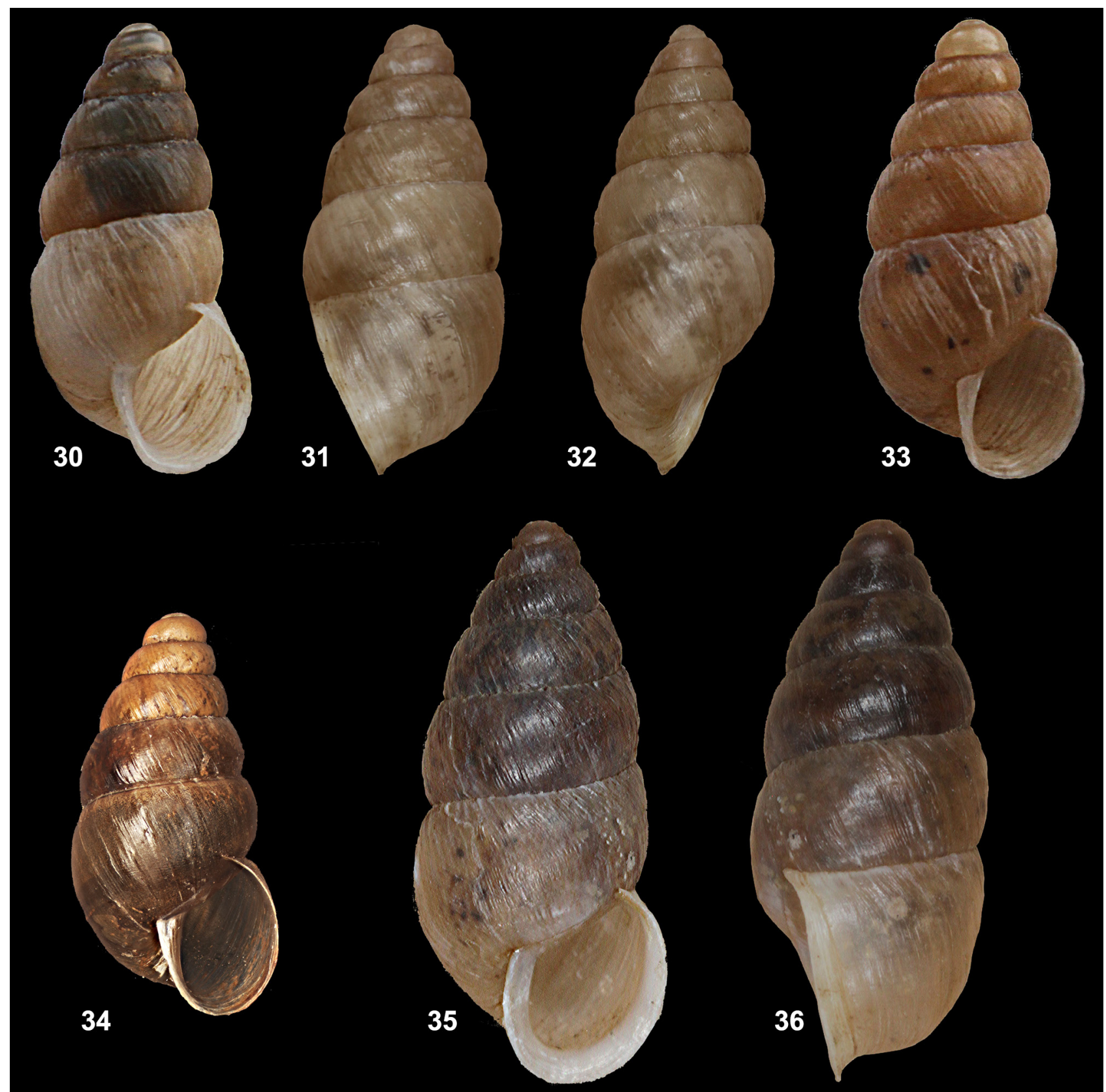

Figs 30-36. Species of Laevozebrinus: 30-32 - Laevozebrinus parvus Gittenberger, Gyeltshen et Leda, n. sp., holotype (NBCB1201), district Paro, 12 km SW of Paro, altitude 3,680 m a.s.1., H 8.4 mm; 33-34 - L. parvus Gittenberger, Gyeltshen et Leda, n. sp. paratypes (NBCB1202): same locality as holotype, H $8.5 \mathrm{~mm}$ (33); (NBCB1145), district Thimphu, road to quarry near Bjimina, $13 \mathrm{~km}$ SW of Thimphu, altitude 2,300 m a.s.l.; H $7.6 \mathrm{~mm}$ (34). 35-36 Laevozebrinus nepalensis Schileyko et Frank, 1994 (RMNH.MOL-WJM Maassen Colln), Nepal, Dhaulagiri zone, Mustang district, Annapurna National Park, right side of Kali-Gandaki valley, NE end of Tukuche village, SE slope NW of GanpaSampa temple, altitude 2,650-2,700 m a.s.l., dry rocks among grass, A. G. KUZNETSOv leg. 07.05.1996, H 10.5 mm 
Description. The shining, fragile shell is slender conical with a blunt apex; it has $5 \frac{1 / 2-61 / 4}{1}$ moderately convex whorls, separated by a deeply incised suture. There is an irregular, vague, colour pattern of light and darker brown, or yellowish brown blotches. The protoconch is fine silky with some spiral lines near the suture; the teleoconch has coarse growth lines and parts with very faint spiral striae. The more or less regularly oval aperture is higher than broad, measuring $35-40 \% \mathrm{H}$; its straight or curved columellar edge is about as long as the parietal interruption, whereas the palatal edge gradually passes into the basal edge. The apertural lip is poorly thickened and little expanded; its uppermost columellar part is curved in front of the very narrow umbilicus. There is a noticeable periostracum.

Measurements $(\mathrm{n}=20)$. H 7.6-9.6 mm, W 3.9$4.6 \mathrm{~mm}$.

Genital tract (Figs 38-40). The entire penis (p) is about as broad as and little narrower than the epiphallus (e). The penial appendix (a) inserts about halfway on the penis; it has a proximal part (a1), with irregular longitudinal lamellae in the lumen which is about as broad as the penis. Its short, globular part (a2), with a transverse luminal structure, is followed by a narrower, short segment (a3), with a meandering structure in the narrow lumen; this is followed by the narrowest segment (a4) with a relatively wide meandering structure and a thin wall, and the elongated bursa (a5) that has a wide lumen and a moderately thick wall. The epiphallus (e) is nearly twice as long as the penis; it has a short blunt flagellum and its most proximal and broadest part (e1) is shorter than half the length of the penis and broader, with an irregular structure in the lumen. After a short narrowing (e2), a longer segment with luminal septa follows (e3); an inconspicuous thickening, the caecum (c) borders the distal part of the epiphallus (e4) with a more irregular lumen and the flagellum (f) with a longitudinal fold. The separate retractor muscles (ra, rp) run from the diaphragm to the distal third of a1 and close to the distal end of the penis. The vagina (v) is clearly broader and shorter than both the penis and the oviductus (o). The pedunculus (pd) is about as long as the diverticulum (d); the globular bursa (b) is connected to the pedunculus with a narrow duct that is as long as its diameter.

In one of the three dissected snails, the genital tract looked different, most probably showing a phase of sexual activity (Fig. 40). Here, most of the male parts are enveloped by a strongly inflated part of the tract, with a conspicuous projection. The epiphallus is easily recognisable because of its flagellum and caecum. Its position in relation to the genital atrium has reversed. The same applies to a4-a5 of the penial appendix. We refrain from speculations about morphology and functionality here.

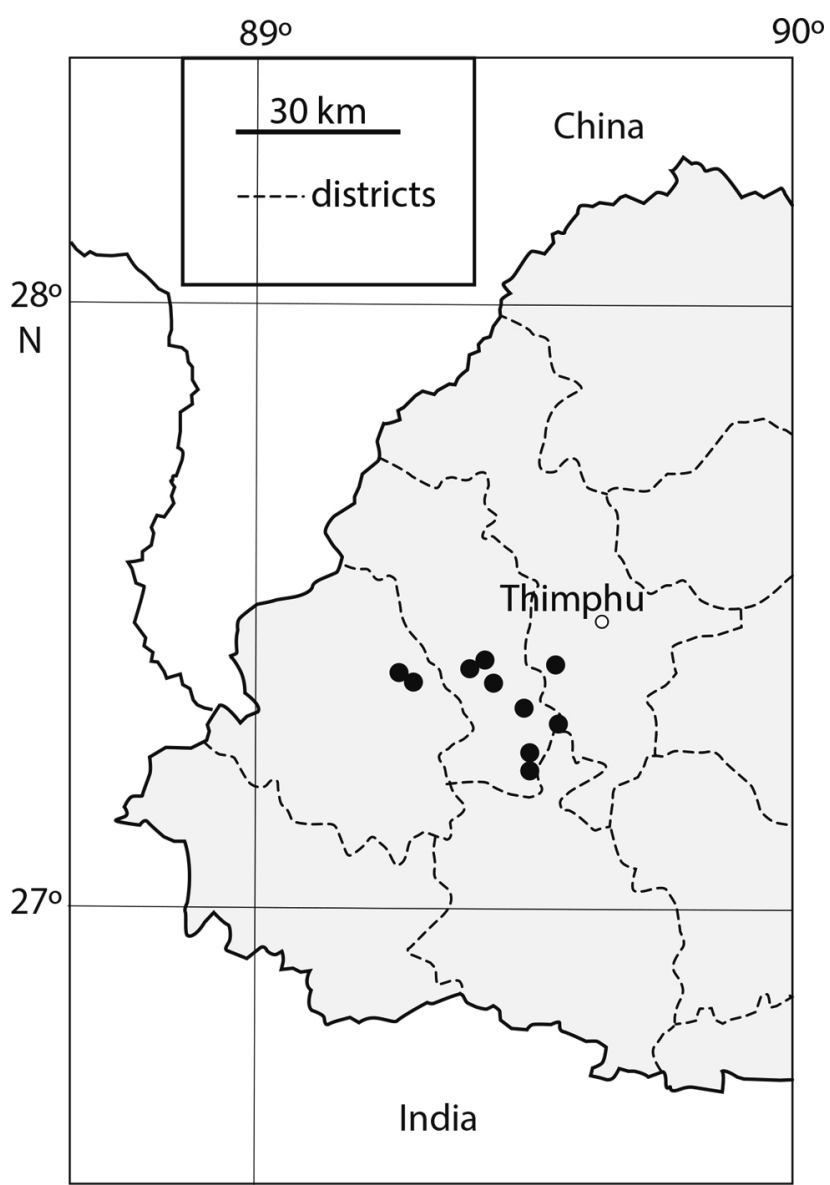

Fig. 37. Records of Laevozebrinus parvus Gittenberger, Gyeltshen et Leda, n. sp.

Differentiation. The geographically closest congeneric subspecies Laevozebrinus nepalensis nepalensis Schileyko et Frank, 1994 (Figs 35-36) and L. nepalensis myagdiensis Kuznetsov et Schileyko, 1997, both from Nepal, differ in stronger, on average smaller shells with a thickened and reflected apertural lip. Their genital tracts differ in the bursa copulatrix that has no diverticulum, in the position of a more prominent caecum about halfway the epiphallus and in the retractor muscles that are united shortly before the attachment to the diaphragma. Laevozebrinus mustangensis Kuznetsov et Schileyko, 1997 from western Nepal is larger; its genital tract differs in a longer, slender flagellum and in the insertion of the retractor muscle near the distal end of al of the penial appendix. Laevozebrinus guttula (Muratov, 1992), as figured by SYSOEV \& SCHILEYKO (2009: fig. 24C), is equally small and only distinguishable by the more oblique attachment of the palatal edge of the aperture and the very narrow columellar margin. Since that species is known from only the SW. Kopet Dagh in Turkmenistan, 3,500 km WNW of Bhutan, we consider a close taxonomic relationship unlikely. 

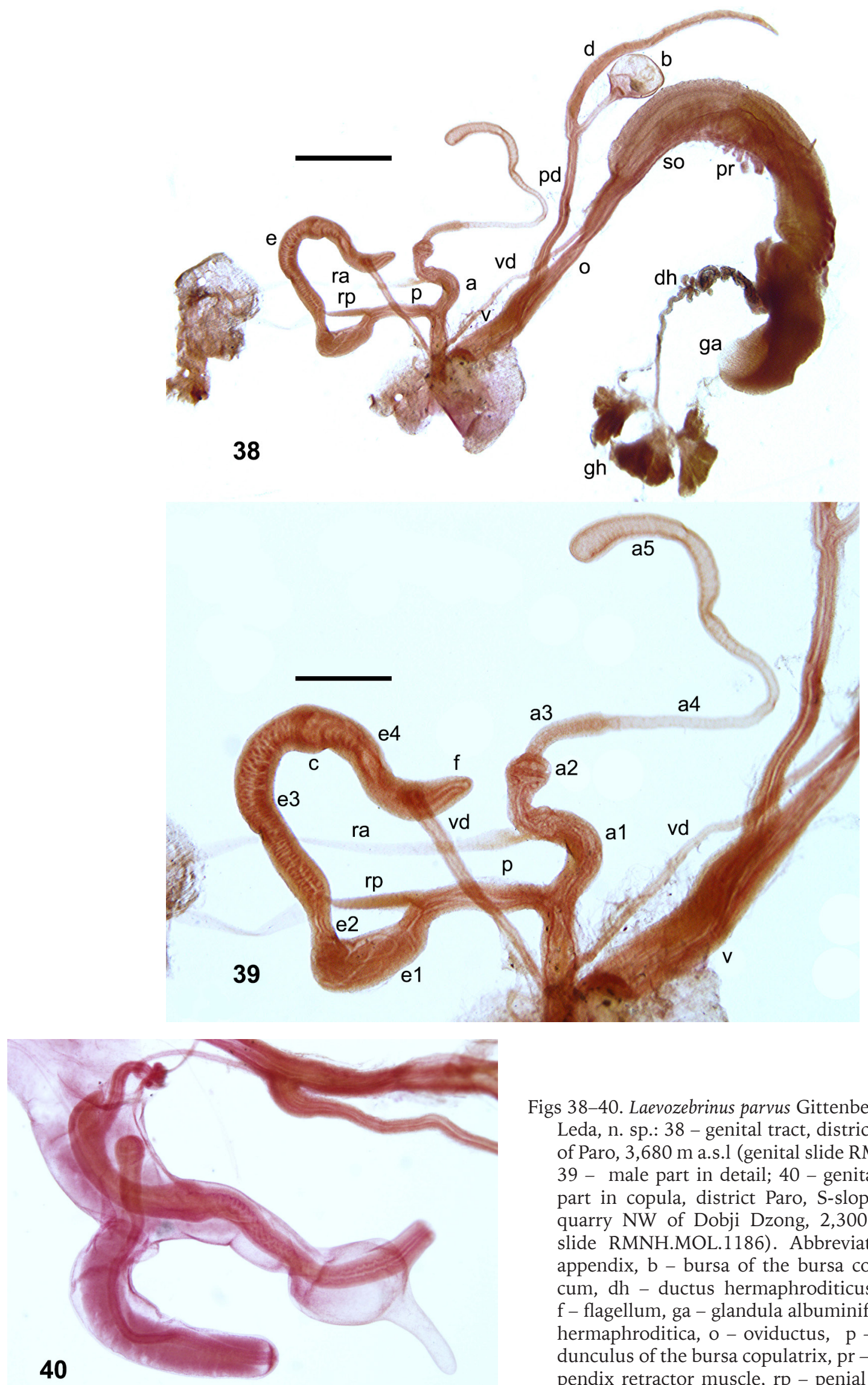

Figs 38-40. Laevozebrinus parvus Gittenberger, Gyeltshen et Leda, n. sp.: 38 - genital tract, district Paro, $12 \mathrm{~km} \mathrm{SW}$ of Paro, 3,680 m a.s.l (genital slide RMNH.MOL.1188); 39 - male part in detail; 40 - genital tract with male part in copula, district Paro, S-slope E of limestone quarry NW of Dobji Dzong, 2,300 m a.s.l. (genital slide RMNH.MOL.1186). Abbreviations: a - penial appendix, b - bursa of the bursa copulatrix, c - caecum, dh - ductus hermaphroditicus, e - epiphallus, $\mathrm{f}$ - flagellum, ga - glandula albuminifera, gh - glandula hermaphroditica, o- oviductus, $\mathrm{p}$ - penis, $\mathrm{pd}-\mathrm{pe}-$ dunculus of the bursa copulatrix, pr - prostate, ra - appendix retractor muscle, $\mathrm{rp}$ - penial retractor muscle, so - spermoviductus, v - vagina, vd - vas deferens 
Etymology. The epithet parvus (Latin: small) refers to the size of this species. It is the smallest enid known from Bhutan.

Distribution. This species was recorded in western Bhutan, in the districts of Paro and Thimphu, at altitudes of 2,040-3,680 $\mathrm{m}$ a.s.l.

\section{Genus Mirus Albers, 1850}

Type species: Bulimus cantorii Philippi, 1844, by monotypy.

Note. Two Mirus species are known from Bhutan now. Their identification is based on only a few empty shells. Both species have unusual distributional patterns, with type localities south of Bhutan in India. Therefore, their identity is questionable.

\section{Mirus nilagiricus (Pfeiffer, 1846)}

Figs 41, 43

Bulimus nilagiricus PfeIfFer (1846: 41), India, Tamil Nadu, Western Ghats, "the Neelgherries", Nilgiri Mts.

Mirus (?) nilagiricus - KUZNETSOV \& SCHILEYKO (1997: 139, fig. 7), BuDHA et al. (2015: 12; 2017: 27).

Mirus nilagiricus - RAHEEM et al. (2014: 65, 184, fig. 37D [lectotype]), GITTENBERGER et al. (2017: 58, fig. 43).

Material. District Bumthang, $5 \mathrm{~km} \mathrm{~S}$ of Jakar, altitude $2,815 \mathrm{~m}, 27^{\circ} 30.32^{\prime} \mathrm{N}, 90^{\circ} 44.23^{\prime} \mathrm{E}$, EGPL leg. 20.04.2015 (NBCB1163). District Chhukha, 24 km $\mathrm{S}$ of Chhuzom, altitude $1,950 \mathrm{~m}$ a.s.l., broadleaf forest along road, $27^{\circ} 06.77^{\prime} \mathrm{N}, 89^{\circ} 32.10^{\prime} \mathrm{E}$; EGCGPL 21.10.2018 (NBCB1164; RMNH.MOL.346830). District Samdrup Jongkhar, $20 \mathrm{~km} \mathrm{~N}$ of Samdrup Jongkhar, altitude $1,680 \mathrm{~m}$ a.s.1.; $26^{\circ} 59.33^{\prime} \mathrm{N}$, 9131.75'E; EGCGKT leg. 29.10.2019 (NBCB1165).

Description. The brown shell is slender conical, with $63 / 4-8$ nearly flat whorls, separated by a hardly incised suture. The irregular growth lines are crossed by weaker, dense, spiral lirae. The umbilicus is very narrow. The white apertural lip is strongly thickened and reflected; it is less regularly U-shaped basally than in the next species because of the more oblique palatal side.

Measurements $(\mathrm{n}=4)$. H $15.2-16.7 \mathrm{~mm}$, B 5.7$7.2 \mathrm{~mm}$.

Distribution. According to RAHEEM et al. (2014: 65), this species is distributed in "the southern part of the Western Ghats", "Northeast India (Khasi and Dafla Hills), and northern Myanmar". KUZNETSOV \& SCHILEYKO (1997: 139) added a record for E Nepal at $2,200 \mathrm{~m}$ a.s.l. The two records in Bhutan, in opposite parts of the country, at altitudes of 1,680 and 1,950 $\mathrm{m}$ a.s.l., extend the patchy distributional pattern in northeastern direction.

Note. KUZNETSOV \& SCHILEYKO (1997: 139) doubted whether all records concerned a single species.

\section{Mirus cf. hanleyana (Kobelt, 1902)}

Figs 42-43

Bulimus nilagiricus - HANLEY \& THEOBALD (1870: 12, pl. 23 fig. 3), not L. Pfeiffer, 1846.

Buliminus (Ena) hanleyanus KoBelt (1902: 931, pl. 131 figs 3-5), India, Tamil Nadu, Western Ghats, "Nilgherrie-Gebirge", Nilgiri Mts).

Mirus hanleyanus - RAHEEM et al. (2014: 65, 184, fig. 37C [lectotype]).

Mirus spec. GiTTENBERGER et al. (2017: 59, fig. 44).

Material. District Chhukha, $24 \mathrm{~km} \mathrm{~S}$ of Chhuzom, altitude 1,950 $\mathrm{m}$ a.s.l., broadleaf forest along road; $27^{\circ} 06.77^{\prime} \mathrm{N}, \quad 89^{\circ} 32.10^{\prime} \mathrm{E} ; \quad$ EGCGPL, 21.10.2018 (NBCB1167). District Pemagatshel, NW-side Pemagatshel, altitude $1,750 \mathrm{~m}$ a.s.l., $27^{\circ} 02.48^{\prime} \mathrm{N}$, 9125.72'E; EGPL 15.04.2015 (NBCB1166).

Description. The yellowish brown shell is slightly less slender conical than $M$. nilagiricus. It has $7-71 / 4$ weakly convex whorls, separated by a hardly incised suture. The irregular growth lines are crossed by weaker, dense, spiral lirae. The umbilicus is very narrow. The whitish apertural lip is clearly thickened and reflected; it is broad U-shaped basally.

Measurements $(n=2)$. H 15.3, B 7.2; H 17.3, B $7.6 \mathrm{~mm}$.

Distribution. According to RAHEEM et al. (2014: 65), this species is "endemic to the Western Ghats". It shares its type locality, Nilgiri Hills, with M. nilagiricus. The two records in Bhutan are in opposite parts of the country, at altitudes of 1,750 and $1,950 \mathrm{~m}$ a.s.l.

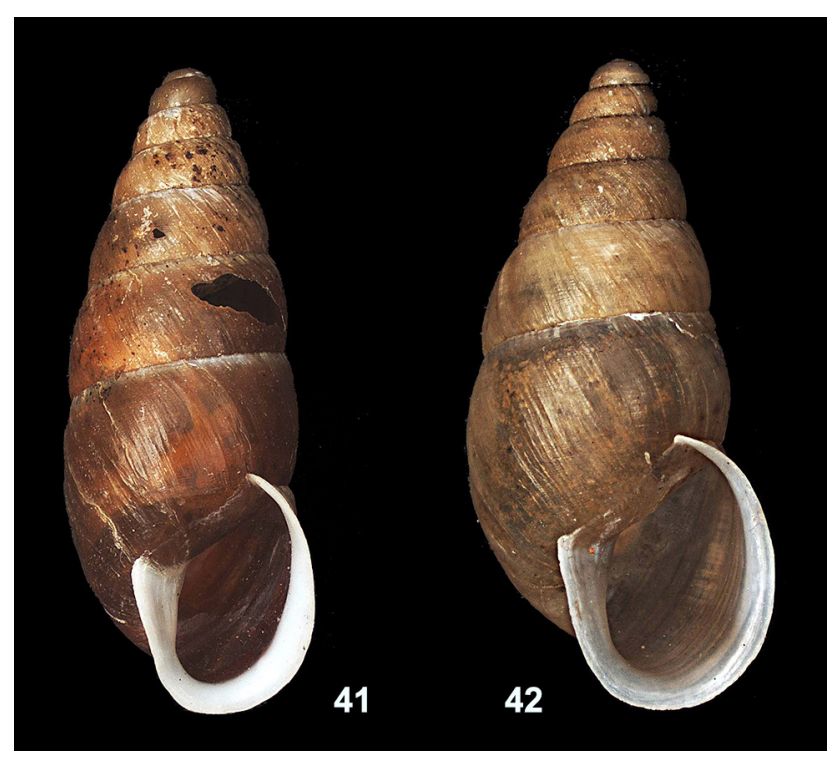

Figs 41-42. Species of Mirus: 41 - Mirus nilagiricus (Pfeiffer, 1846) (NBCB1163), district Bumthang, $5 \mathrm{~km}$ S of Jakar, altitude 2,815 m, H $15.2 \mathrm{~mm}, 42$ - M. cf. hanleyana (Kobelt, 1902) (NBCB1166), district Pemagatshel, NWside Pemagatshel, altitude 1,750 m a.s.l., H $15.3 \mathrm{~mm}$ 


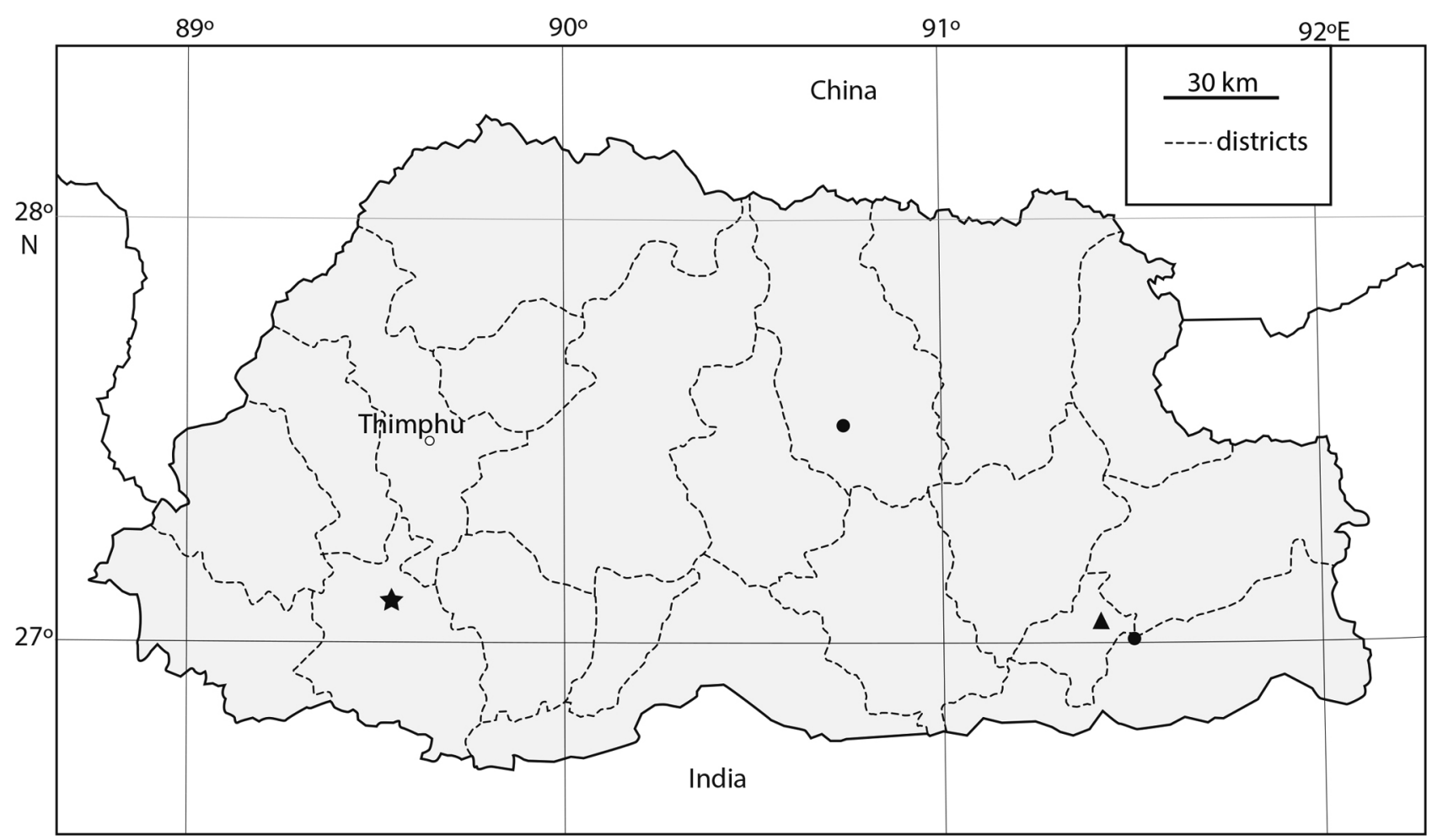

Fig. 43. Records of Mirus nilagiricus (Pfeiffer, 1846) (dots) and M. cf. hanleyana (Kobelt, 1902) (triangle) or both species (star)

Notes. We doubtfully use the epithet hanleyana for this species. The connection of the outer lip to the columellar lip is angular in the lectotype (RAHEEM et al. 2014: fig. 37C), whereas it is much more gradual in the original drawings for the species (KOBELT 1902: pl. 131 figs 3, 4). Since the basal angularity could be an individual aberration, we studied both the lectotype and the only known paralectotype of this species. Photos of these specimens were made available by courtesy of Ms. Sigrid Hof (Forschungsinstitut und Naturmuseum Senckenberg, Frankfurt am Main, Germany) and are reproduced here. In conformity with the original drawings, the basal part of the ap- erture is regularly rounded in the paralectotype and angular in the lectotype, that has no growth lines indicative of former breakage and repair. The relative size of the aperture is also quite different in both shells. In that respect, the two shells from Bhutan correspond with the lectotype of $M$. hanleyana.

For the time being, we here follow GUDE (1914: 233), who described a mixed sample of M. nilagiricus and $M$. hanleyana, emphasising differences that are recognisable very well in our specimens. The large disjunction between the type locality in southern India and our record for Bhutan strongly reminds of the biogeographically curious records for $M$. nilagiricus.

\section{DISCUSSION}

The largest species diversity of Pupilloidea and Enoidea was found in the western districts of Haa, Paro and Thimphu, which can be regarded as a biogeographical entity. In their distribution, both the genera and the species in that area are quite diverse. The genera Pupilla and Vallonia are Holarctic (ZILCH 1959: 166, GERBER 1996), and contribute with a widespread Asian and a local SE Himalayan species, viz. P. turcmenia and $V$. costohimala, respectively. Truncatellina may be considered a Palaearctic genus (ZILCH 1959: 148), despite the occurrence of T. sykesii (Melvill et Ponsonby, 1893) in S. Africa (VAN BRUGGEN 1978: 920); it is represented by the endemic T. bhutanensis. The genus Gastrocopta, which cannot be classified unequivocally in a biogeographic category (see ZILCH 1959: 160-162), was recorded with G. huttoniana, that has a relatively wide Asian range. The poorly known genus Pupisoma, that was represented by the endemic $P$. paroense, also does not fit clearly in any of the biogeographical categories (see ZILCH 1959: 174). The genera Pseudonapaeus and Laevozebrinus, each with an endemic Bhutanese species in the western districts of Bhutan, viz. P. occibhutanus and L. parvus, are both restricted to the Asian part of the western and central Palaearctis (SCHILEYKo 1998: 196, 198). Only the two Mirus species, both with disjunct Bhutanese-Indian ranges (RAHEEM et al. 2014: 65), are Indo-Malayan; the few 
records suggest that they are not restricted to a particular part of southern Bhutan. The distributional pattern of Bensonella plicidens s. lat., a species which is reported from a zone of $6,000 \mathrm{~km}$ between $22^{\circ} \mathrm{N}$ and $35^{\circ} \mathrm{N}$, with only one record in eastern Bhutan, is exceptional.

While considering the distributional patterns, it should be taken into account that large parts of western Bhutan are still unexplored. There are no records, for example, from the western district of Samtse. Ongoing research in India and Nepal may show whether the species that are referred to as endemic here, are endemic indeed. Despite this fact, we may already conclude however, that there is a considerable percentage of endemism in the malacofauna of Bhutan. That conclusion is based on the present and various previous taxonomic analyses. Three of the four species of Rahula Godwin-Austen, 1907 (Euconulidae H. B. Baker, 1928) (GITTENBERGER et al. 2021), all six species of Phaedusinae A. J. Wagner, 1922 (Clausiliidae Gray, 1855) (GITTENBERGER et al. 2019b), three of the four species of Endothyrella Zilch, 1960 (Plectopulidae Möllendorff, 1898) (GITTENBERGER et al. 2018b) and one of four species of Pupinidae L. Pfeiffer, 1853 (GitTEnBerger et al. 2019a) are considered endemic on the basis of the available data.

\section{REFERENCES}

Albers J. C. 1850. Die Heliceen nach natürlicher Verwandtschaft systematisch geordnet. Enslin, Berlin.

BAKER H. B. 1928. Minute American Zonitidae. Proceedings of the Academy of Natural Sciences of Philadelphia 80: $1-44$.

BANK R. A., NeUbert E. 1998. Notes on Buliminidae, 5. On the systematic position of Arabian Buliminidae (Gastropoda Pulmonata), with the description of a new genus. Basteria 61: 73-84.

BANK R. A., NEUBERT E. 2016. Notes on Buliminidae, 7 Revision of the Enidae of Iran, with special reference to the collection of Jacques de Morgan (Gastropoda: Pulmonata). Vita Malacologica 14: 1-84.

BENSON W. H. 1849. Description of four new Asiatic species of the genus Pupa of Draparnaud. The Annals and Magazine of Natural History (2) 4: 125-128.

BENSON W. H. 1856. New land snails collected by E. L. Layard, Esq. Annals and Magazine of Natural History 18: 433-439.

BENSON W. H. 1863. Characters of new operculate landshells from the Andamans, and of Indian and Burmese species of Pupa. The Annals and Magazine of Natural History (3) 12: 425-429.

BENSON W. H. 1864. Characters of Coilostele, an undescribed genus of Auriculacea (?), and of species of Helix, Pupa, and Ancylus, from India, West Africa, and

\section{ACKNOWLEDGEMENTS}

We thank Dr TASHI Y. DORJI, former Program Director of the NBC (Serbithang, Thimphu, Bhutan) and Ms SANGAY DEMA (NBC) for their support and guidance to carry out this research. We also thank two referees for constructive remarks that enabled us to improve the text. For various kinds of support or assistance we thank Dr R. A. BANK (Hoogezand, The Netherlands), the late Dr U. BÖSSNECK (Naturkundemuseum Erfurt, Germany), Dr P. BoucheT (Musée National d'Histoire Naturelle, Paris, France), Dr P. B. BudHA (Tribhuvan University, Kathmandu, Nepal), Dr J. GERBER (Field Museum of Natural History, Chicago, USA), Dr C.-C. HWANG (National University of Kaohsiung, Taiwan), Ir H. P. M. G. MenKHORST (Krimpen aan de IJssel, The Netherlands), and Dr R. PREECE (University Museum of Zoology, Cambridge, U.K.). We are grateful to $\mathrm{Mr}$ E.-J. BOsCH (National Biodiversity Center Naturalis, Leiden, The Netherlands), who composed the distribution maps, to Ms S. HoF (Forschungsinstitut Senckenberg, Frankfurt am Main, Germany), who located and photographed type specimens, and to Ms B. J. VAN HEUveN (National Biodiversity Center Naturalis, Leiden, The Netherlands) who took the SEM photos.

Ceylon. The Annals and Magazine of Natural History (3) 13: 136-140.

BlANFORD W. T., GODWIN-AUSTEN H. H. 1908. Mollusca. Testacellidae and Zonitidae. The Fauna of British India, including Ceylon and Burma [Vol. I]. Taylor and Francis, London.

BOETTGER O. 1889. Die Binnenmollusken Transkaspiens und Chorassans. Zoologische Jahrbücher. Abtheilung für Systematik, Geographie und Biologie der Thiere 4: 925-982, pls 26-27.

BÖSSNECK U., MENG S. 2018. Ökologie und Verbreitung der Gattung Gastrocopta in Nepal (Mollusca: Gastropoda: Vertiginidae). In: HARTMANN C., BARCLAY M., WEIPER T. J. (eds). Biodiversität und Naturausstattung im Himalaya VI. Verein der Freunde \& Förderer des Naturkundemuseums Erfurt e.V., Erfurt, pp. 135-141.

BOUCHET P., ROCROI J.-P., HAUSDORF B., KAIM A., KANO Y., NÜTZEL A., PARKHAEV P., SCHRÖDL M., STRONG E. E. 2017. Classification and nomenclator of gastropod families. Malacologia. International Journal of Malacology 61: 1-526. https://doi.org/10.4002/040.061.0201

BUDHA P. B., BACKELJAU T. 2017. First report of Paraboysidia landourensis (Pilsbry, 1915) from Nepal, with description of a putative new species and a note on Bensonella plicidens (Benson, 1849) (Stylommatophora: family unclear). In: BUDHA P. B. Taxonomy of terrestrial mol- 
luscs of Nepal. PhD dissertation, Evolutionary Ecology Group, University of Antwerp, Antwerp, Belgium, pp. 189-201.

BudhA P. B., NAggs F., BACKeljau T. 2015. Annotated checklist of the terrestrial gastropods of Nepal. ZooKeys 492: 1-48.

https://doi.org/10.3897/zookeys.492.9175

Budha P. B., Naggs F., Backeljau T. 2017. Annotated checklist of the terrestrial gastropods of Nepal. In: BUDHA P. B. Taxonomy of terrestrial molluscs of Nepal. PhD dissertation, Evolutionary Ecology Group, University of Antwerp, Antwerp, Belgium, pp. 17-58.

DRAPARNAUD J. P. R. 1801. Tableau des mollusques terrestres et fluviatiles de la France. Renaud, Montpellier \& Bossange, Masson et Besson, Paris.

FLEMING J. 1828. A history of British animals: exhibiting the descriptive characters and systematical arrangement of the genera and species of quadrupeds, birds, reptiles, fishes, mollusca, and radiata of the United Kingdom; including the indigenous, extirpated, and extinct kinds, together with periodical and occasional visitants. Bell \& Bradfute, Edinburgh.

Gerber J. 1996. Revision der Gattung Vallonia Risso 1826 (Mollusca: Gastropoda: Valloniidae). Schriften zur Malakozoologie aus dem Haus der Natur - Cismar 8: $1-227$.

Gerber J., BÖsSNECK U. 2009. The genus Vallonia in Nepal (Gastropoda: Pulmonata: Valloniidae). Archiv für Molluskenkunde 138: 43-52.

https://doi.org/10.1127/arch.moll/0003-9284/138/ 043-052

GitTenbergen E. 1983. Beiträge zur Kenntnis der Pupillacea. IX. Nochmals über Orculidae. Proceedings of the Koninklijke Nederlandse Akademie van Wetenschappen (C) 86: 325-342.

GiTTENBERGER E. 1996. Adaptations of the aperture in terrestrial gastropod-pulmonate shells. Netherlands Journal of Zoology 46: 191-205.

Gittenberger E., LedA P., Gyeltshen C., Sherub S. 2018a. Distributional patterns of molluscan taxa in Bhutan (Mollusca). In: HARTMANN C., BARCLAY M., WEIPER T. J. (eds). Biodiversität und Naturausstattung im Himalaya VI. Verein der Freunde \& Förderer des Naturkundemuseums Erfurt e. V., Erfurt, pp. 143-151.

Gittenberger E., LedA P., Gyeltshen C., Sherub S., DEMA S. 2017. A field guide to the common molluscs of Bhutan. National Biodiversity Centre, Thimphu.

GitTenberger E., LedA P., Sherub S. 2013. Bhutanese snails, the smallest one: Truncatellina bhutanensis $\mathrm{n}$. sp. (Gastropoda, Pulmonata, Vertiginidae). Basteria 77: 29-32.

GitTenberger E., LedA P., Sherub S., Gyeltshen C. 2019a. The family Pupinidae in Bhutan (Gastropoda: Caenogastropoda: Cyclophoroidea). Folia Malacologica 27: 203-209.

https://doi.org/10.12657/folmal.027.019

GitTEnBERGER E., LeDA P., SHERUB S., GyeltShen C. $2019 \mathrm{~b}$. The subfamily Phaedusinae in Bhutan (Gastropoda, Pulmonata, Clausiliidae). Basteria 83: 133-144.
GitTenberger E., LedA P., Sherub S., Gyeltshen C. 2021. Rahula revisited (Pulmonata: Euconulidae), with data for Bhutan, India (Assam), Laos, Vietnam and Indonesia, including two new species. Journal of Conchology 44: 11-19.

Gittenberger E., LedA P., Sherub S., PÁll-Gergely B. 2018b. Endothyrella Zilch, 1960 in Bhutan (Gastropoda: Pulmonata: Plectopylidae) with a description of three new species. Archiv für Molluskenkunde 147: 203-213. https://doi.org/10.1127/arch.moll/147/203-213

GODWIN-AUSTEN H. H. 1907. Land and freshwater Mollusca of India, including South Arabia, Baluchistan, Afghanistan, Kashmir, Nepal, Burmah, Pegu, Tenasserim, Malay Peninsula, Ceylon, and other islands of the Indian Ocean. Supplementary to Messrs. Theobald and Hanley's Conchologia Indica. London, Taylor \& Francis. Vol. 2(10): 147-238, pls 101-117.

GRAY J. E. 1855. Catalogue of Pulmonata or air-breathing Mollusca in the collection of the British Museum, Part I. Taylor \& Francis, London.

GUDE G. K. 1914. The fauna of British India, including Ceylon and Burma. Mollusca [II]: i-xii, 1-520. Taylor and Francis, London.

Hanley S. C. T., TheObald W. 1870-1876. Conchologia Indica: Illustrations of the land and freshwater shells of British India. L. Reeve \& Company, London. [Dates of publication (after PRASHAD 1927): pp. 1-18, pls. 1-40 (1870); pp. 19-28, pls. 41-60 (1872); pp.29-34. pls. 61-80 (1873); pp. 35-48, pls. 81-120 (1874); pp. 49-56, pls. 121-140 (1875); pp. xviii + 57-65, pls. $141-160$ (1876)].

Hemming F. (ed.) 1955. Opinion 335. Addition to the Official List of Generic Names in Zoology of the names of thirty-four non-marine genera of the phylum Mollusca. Opinions and Declarations rendered by the International Commission on Zoological Nomenclature 10: $45-76$.

Hemming F. (ed.) 1957. Direction 72. Completion and in certain cases correction of entries relating to the names of genera of the phyla Mollusca, Brachiopoda, Echinodermata and Chordata made on the "Official List of Generic Names in Zoology" by rulings given in "Opinions" rendered in the period up to the end of 1936. Opinions and Declarations rendered by the International Commission on Zoological Nomenclature 1 E (E.11): 163-171.

HWANG C.-C. 2014. A new subspecies of land snail Bensonella plicidens lakainguta (Gastropoda, Vertiginidae) from southern Taiwan. Bulletin of Malacology, Taiwan 37: 15-26.

Kobelt W. 1902. Die Familie Buliminidae. In: Systematisches Conchylien-Cabinet von Martini und Chemnitz (1)13 (2, 473): 901-956, pls 129-133.

KuZnetsov A. G., SCHILEYKo A. A. 1997. New data on Enidae (Gastropoda, Pulmonata) of Nepal. Ruthenica 7: 133-140.

LINDHOLM W. A. 1922. Description of two Bulimini (Gastropoda Pulmonata) from Russian Central Asia. Annuaire du Musée zoologique de l'Académie des Sciences de Russie 23: 273-275. 
LINDHOLM W. A. 1925. Beitrag zur Systematik und Nomenklatur der Familie Enidae (Buliminidae). Archiv für Molluskenkunde 57: 23-41.

LINNAEUS C. 1758. Systema Naturae per regna tria naturae, secundum classes, ordines, genera, species, cum characteribus, differentiis, synonymis, locis. Editio decima, reformata Laurentius Salvius: Holmiae.

LOWE R. T. 1852. Brief diagnostic notices of new Maderan land shells. Annals and Magazine of Natural History, (2) 9(50), 112-120, 275-279.

MARTENS E. VON 1874. Sliznyaki (Mollusca). In: FEDCHENKo A. P. (ed.). Puteshestvie v Turkestan. Vypusk I. Tom II. Zoogeograficheskiya Izslydovaniya. Chast I. S-Peterburg, Moskva, pp. [1-10], 1-66.

MARTENS E. VON 1880. Conchologische Mittheilungen als Fortsetzung der Novitates Conchologicae. Erster Band. Fischer, Kassel.

Melvill J. C., Ponsonby J. H. 1893. Descriptions of thirteen new species of terrestrial Mollusca from South Africa. The Annals and Magazine of Natural History (6) 11(61): 19-24.

MENG S. 2008. Pupilla talassika n. sp. (Gastropoda: Pulmonata: Pupillidae) from the late Pleistocene loess from West Talasskij Alatau (South Kazakhstan) with comments on the distribution range of Pupilla triplicata (Studer, 1820) in Central Asia. Mollusca 26: 221-228.

MORSE E. S. 1864. Observations on the terrestrial Pulmonifera of Maine, including a catalogue of all the species of terrestrial and fluviatile Mollusca known to inhabit the state. Journal of the Portland Society of Natural History 1: 1-63.

MÖLLENDORFF O. VON 1898. Verzeichniss der auf den Philippinen lebenden Landmollusken. Abhandlungen der Naturforschenden Gesellschaft zu Görlitz 22: 26208.

MurAtov I. V. 1992. New taxa of Pseudonapaeinae (Gastropoda, Pulmonata, Enidae). Ruthenica 2: 37-44.

MÜLlER O. F. 1774. Vermium terrestrium et fluviatilium, seu animalium infusorium, Helminthicorum, et testaceorum, non marinorum, succincta historia. Havniae et Lipsiae, apud Heineck et Faber, ex officina Molleriana.

NekOla J. C., COlEs B. F., HorsÁK M. 2014. Species assignment in Pupilla (Gastropoda: Pulmonata: Pupillidae) integration of DNA-sequence data and conchology. Journal of Molluscan Studies 81[2015]: 196-261. https://doi.org/10.1093/mollus/eyu083

PFEIFFER L. 1846. Descriptions of twenty new species of Helicea, in the collection of $\mathrm{H}$. Cuming, Esq. Proceedings of the Zoological Society of London 12: $37-41$.

PFEIFFER L. 1853. Monographia heliceorum viventium: sistens descriptiones systematicas et criticas omnium hujus familiae generum et specierum hodie cognitarum. F. A. Brockhaus, Lipsiae.

PFEIFFER L. 1857. Descriptions of fifty-eight new species of Helicea from the collection of H. Cuming, Esq. Proceedings of the Zoological Society of London 24: 324-336.
PHILIPPI R. A. 1844. Descriptiones testaceorum quorundam novorum, maxime chinensium. Zeitschrift für Malakozoologie 1: 161-167.

Pilsbry H. A. 1916. [Pupillidae (Gastrocoptinae)] Descriptions of genera and species. Manual of Conchology. Second Series: Pulmonata 24 (93): 1-112, pls 1-13.

PILsBry H. A. 1917. Pupillidae (Gastrocoptinae). Manual of Conchology. Second Series: Pulmonata 24: 113-176, pls 14-29.

PILSBRY H. A. 1918. Pupillidae (Gastrocoptinae). Manual of Conchology. Second Series: Pulmonata 24: i-xii, 257-380, pls 39-49.

PILsBry H. A. 1920. Pupillidae (Vertigininae, Pupillinae). Manual of Conchology. Second Series: Pulmonata 26 (101): 1-64, pls 1-8.

PILsbry H. A. 1921. Pupillidae (Vertigininae, Pupillinae). Manual of Conchology. Second Series: Pulmonata 26 (103): 129-192, pls 14-18; (104): 193-254, pls 19-24.

Pilsbry H. A. P., VANATTA E. G. 1900. A partial revision of the Pupae of the United States. Proceedings of the Academy of Natural Sciences 52: 582-596.

POKRYsZKo B. M., AufFENBERG K., HLAVÁČ J. Č., NAGGS F. 2009. Pupilloidea of Pakistan (Gastropoda: Pulmonata): Truncatellinae, Vertigininae, Gastrocoptinae, Pupillinae (in part). Annales Zoologici 59: 423-458.

PRASHAD B. 1927. On the dates of publication of Hanley and Theobald's "Conchologia Indica". Journal and Proceedings of the Asiatic Society of Bengal, New Series 22: 129-130.

Raheem D. C., Budha P. B., Naggs F., Preece R. C. 2010. An illustrated guide to the land snails of Nepal. The Natural History Museum, London.

Raheem D. C., Taylor H., Ablett J., Preece R. C., ARAVIND N. A., NAGGS F. 2014. A systematic revision of the land snails of the Western Ghats of India. Tropical Natural History, Supplement 4: i-xiv, 1-294.

RAMAKRISHNA, Mitra S. C., DEY A. 2010. Annotated checklist of Indian land molluscs. Records Zoological Survey of India. Occasional Paper 306.

RISSO A. 1826. Histoire naturelle des principales productions de l'Europe méridionale, volume 4. Levrault, Paris.

SCHILEYKO A. A. 1984. Nazemnye mollyuski podotryada Pupillina fauny SSSR (Gastropoda, Pulmonata, Geophila). Fauna SSSR, Mollyuski. III, 3 [= N.S. 130]. Nauka, Leningrad.

SCHILEYKO A. A. 1998. Treatise on recent terrestrial molluscs. Ruthenica Supplement 2: 1-127.

SCHILEYKO A., FRANK C. 1994. Some terrestrial mollusca of the Nepalesian fauna. Archiv für Molluskenkunde 123: $127-136$. https://doi.org/10.1127/arch.moll/123/1994/127

SCHILEYKO A. A., RYMZHANOV T. S. 2013. Fauna nazemnykh mollyuskov (Gastropoda, Pulmonata terrestria) Kazakhstana i sopredel'nykh territoriy. KMK Scientific Press, Moscow - Almaty.

STEENBERG C. M. 1917. Anatomie des Acanthinula et des Vallonia. Les organes génitaux. Videnskabelige 
Meddelelser fra Dansk Naturhistorisk Forening i København 69: 1-15.

STEENBERG C. M. 1925. Études sur l'anatomie et la systématique des maillots (fam. Pupillidae s. lat.). Videnskabelige Meddelelser fra Dansk Naturhistorisk Forening i København 80: 1-202.

STOLICZKA F. 1871. Notes on terrestrial Mollusca from the neighbourhood of Moulmein (Tenasserim Provinces), with descriptions of new species. The Journal of the Asiatic Society of Bengal, Part II, 40: 143-177.

STOLICZKA F. 1873. On the land-shells of Penang island, with descriptions of the animals and anatomical notes; part second, Helicacea. The Journal of the Asiatic Society of Bengal, Part II, 42: 11-38.

STUDER S. 1820. Kurzes Verzeichnis der bis jetzt in unserm Vaterlande entdeckten Conchylien. Naturwissenschaftlicher Anzeiger der Allgemeinen Schweizerischen Gesellschaft für die Gesammten Naturwissenschaften 3: 83-94.

SysOeV A., SCHILEYKO A. 2009. Land snails and slugs of Russia and adjacent countries. Pensoft, Sofia - Moscow.

THEOBALD W. 1878. Notes on the land and fresh-water shells of Kashmir, more particularly of the Jhilum valley below Srinagar and the hills North of Jamu. Journal of the Asiatic Society of Bengal 47: 141-149.

TURTON W. 1831. A manual of the land and fresh-water shells of the British Islands. Longman, Rees, Orme, Brown \& Greene, London.

VAN BRUgGen A. C. 1978. Land molluscs. In: WeRGER M. J. A., VAN BRUGGEN A. C. (eds). Biogeography and ecology of southern Africa. Dr. W. Junk, The Hague, pp. 877-923.

VOITH I. VON 1840. (in FÜRNROHR A. E. Animalia mollusca. Mit Anmerkungen von I. v. Voith). In: FÜRNROHR A.
E. (ed.). Naturhistorische Topographie von Regensburg. In Verbindung mit Forster, Herrich-Schäffer, Koch, von Schmöger und von Voith. Dritter Band, die Fauna von Regensburg enthaltend. Regensburg: 459-478.

WADA S., CHIBA S. 2013. The dual protection of a micro land snail against a micro predatory snail. PLOS ONE 8: 1-5 [E54123]. https://doi.org/10.1371/journal.pone.0054123

WAGNER A. J. 1922. Uzupełnienia i przyczynki do systematyki Clausiliidów. Ergänzungen und Erläuterungen zur Systematik der Clausiliiden. Annales Zoologicae Musei Polonici Historiae Naturalis 1: 96-111.

WESTERLUND C. A. 1887. Fauna der in der paläarctischen Region (Europa, Kaukasien, Sibirien, Turan, Persien, Kurdistan, Armenien, Mesopotamien, Kleinasien, Syrien, Arabien, Egypten, Tripolis, Tunesien, Algerien und Marocco) lebenden Binnenconchylien. III. Gen. Buliminus, Sesteria, Pupa, Stenogyra \& Cionella. Håkan Ohlsson, Lund.

Wollaston T. V. 1878. Testacea Atlantica or the land and freshwater shells of the Azores, Madeiras, Salvages, Canaries, Cape Verdes, and Saint Helena. Reeve. London.

WOODWARD B. B. 1903. List of British non-marine Mollusca. Journal of Conchology 10: 352-367.

ZILCH A. 1959-1960. Gastropoda. Euthyneura [part.]. Handbuch der Paläozoologie 6: 1-400 [1959], 401-835, i-xii [1960]. Borntraeger, Berlin.

Received: February 27th, 2021

Revised: April 7th, 2021

Accepted: April 22nd, 2021

Published on-line: May 25th, 2021 